\title{
Protein Synthesis in Distal Axons Is Not Required for Growth Cone Responses to Guidance Cues
}

\author{
Florence K. Roche, Bonnie M. Marsick, and Paul C. Letourneau \\ Department of Neuroscience, Graduate Program in Neuroscience, University of Minneapolis, Minneapolis, Minnesota 55455
}

\begin{abstract}
Recent evidence suggests that growth cone responses to guidance cues require local protein synthesis. Using chick neurons, we investigated whether protein synthesis is required for growth cones of several types to respond to guidance cues. First, we found that global inhibition of protein synthesis stops axonal elongation after $2 \mathrm{~h}$. When protein synthesis inhibitors were added 15 min before adding guidance cues, we found no changes in the typical responses of retinal, sensory, and sympathetic growth cones. In the presence of cycloheximide or anisomycin, ephrin-A2, slit-3, and semaphorin $3 \mathrm{~A}$ still induced growth cone collapse and loss of actin filaments, nerve growth factor (NGF) and neurotrophin-3 still induced growth cone protrusion and increased filamentous actin, and sensory growth cones turned toward an NGF source. In compartmented chambers that separated perikarya from axons, axons grew for $24-48 \mathrm{~h}$ in the presence of cycloheximide and responded to negative and positive cues. Our results indicate that protein synthesis is not strictly required in the mechanisms for growth cone responses to many guidance cues. Differences between our results and other studies may exist because of different cellular metabolic levels in in vitro conditions and a difference in when axonal functions become dependent on local protein synthesis.
\end{abstract}

Key words: growth cone; guidance; protein synthesis; axon; actin; RhoA

\section{Introduction}

Neurons are highly polarized with elaborate shapes and highly localized activities. Protein synthesis is not confined to the perikaryon; rather, proteins made in dendrites and axons have important functions (Steward and Schuman, 2003). Defective dendritic protein translation underlies some behavioral deficits and mental retardation (Bramham and Wells, 2007; Dahm and Macchi, 2007; Wang et al., 2007). Axonal protein synthesis is critical in functions of terminals, as well as in development and regeneration (Koenig and Giuditta, 1999; Campenot and Eng, 2000; Zhang and Poo, 2002; Piper and Holt, 2004; Verma et al., 2005; Twiss and van Minnen, 2006; Hengst and Jaffrey, 2007).

Is local protein synthesis important in axonal growth and guidance? In vitro experiments with compartmented chambers indicate that axonal protein synthesis is not required for axonal growth (Eng et al., 1999; Blackmore and Letourneau, 2007), yet there are reports that responses to guidance cues require axonal protein synthesis (Campbell and Holt, 2001; Guirland et al., 2003; Brunet et al., 2005; Wu et al., 2005; Leung et al., 2006; Piper et al., 2006; Yao et al., 2006; Lin and Holt, 2007; Farrar and Spencer, 2008). When growth cones enter new environments, local synthesis of receptors could sensitize growth cones to new guidance cues (Brittis et al., 2002). In addition, growth cone ad-

Received Aug. 12, 2008; revised Nov. 4, 2008; accepted Dec. 2, 2008.

This work was supported by National Institutes of Health Grant HD19950 (P.C.L.), National Eye Institute Training Grant EY07133 (B.M.M.), and a grant from the Minnesota Medical Foundation. We thank Dr. Gianluca Gallo and Dr. Lorene Lanier for helpful comments.

Correspondence should be addressed to Paul C. Letourneau, Department of Neuroscience, Graduate Program in Neuroscience, University of Minneapolis, 6-145 Jackson Hall, Minneapolis, MN 55455. E-mail: letou001@umn.edu. DOI:10.1523/JNEUROSCI.3845-08.2009

Copyright $\odot 2009$ Society for Neuroscience $\quad$ 0270-6474/09/290638-15\$15.00/0 aptations to changed balances of cues may involve local synthesis of receptors or signaling components (Ming et al., 2002).

Thus, local synthesis of receptors or signaling components may be necessary for growth cone navigation. Is it also necessary to locally make proteins with general roles in growth cone motility? Recent papers report that RhoA GTPase and $\beta$-actin must be rapidly and locally synthesized for growth cones to respond to several cues (Wu et al., 2005; Leung et al., 2006; Yao et al., 2006). In light of the diverse mechanisms that rapidly regulate RhoA and $\beta$-actin activity, it is unexpected that these components must be locally synthesized to enable responses to guidance cues.

Because previous studies involved few neuronal types, we investigated whether protein synthesis is required for growth cones of other neurons to respond to guidance cues. First, we found that globally inhibiting protein synthesis leads to slowing and arrest of axonal growth over several hours. When protein synthesis inhibitors were added before several positive and negative cues, we found normal growth cone responses. Repulsive cues, ephrin-A2, slit-3, Semaphorin3A (Sema3A), and Semaphorin6A (Sema6A), induced growth cone collapse in the presence of protein synthesis inhibitors. Filamentous actin (F-actin) polymer was lost after adding repulsive cues. Furthermore, attractive cues, nerve growth factor (NGF) and neurotrophin-3 (NT-3), induced growth cone protrusion and increased F-actin despite inhibiting protein synthesis. In addition, growth cones turned toward an NGF source in the presence of protein synthesis inhibitors. In compartmented cultures in which axonal protein synthesis was inhibited for many $\mathrm{h}$, growth cones still responded to guidance cues. Our data indicate that protein synthesis in distal axons of chick retinal, sympathetic, and dorsal root ganglia (DRG) neurons and mouse DRG neurons is not required for responses to several guidance cues. 


\section{Materials and Methods}

Materials. F-12 medium, DMEM medium, B27 additives, laminin, polyD-lysine, Alexa Fluor 488-phalloidin, Alexa Flour 568 secondary antibodies, Click-iT AHA (catalog \#C10102) and Click-iT Tetramethylrhodamine Protein Analysis Detection kit (catalog \#C33370) reagents were purchased from Invitrogen. NGF, NT-3, L1-Fc, slit-3, ephrin-A2-Fc, Sema3A-Fc, and Sema6A-Fc were purchased from R \& D Systems. AntiRhoA monoclonal antibodies were purchased from Santa Cruz Biotechnology, and anti-eIF-4EBP-P rabbit antibodies were purchased from Cell Signaling Technology. Rabbit anti- $\beta$-actin was a gift from Dr. James Ervasti (University of Minnesota, Minneapolis, MN) (Prins et al., 2008). Collagen was purchased from Inamed. Cycloheximide and anisomycin were purchased from Calbiochem, and MG-132 ( $N$-[(phenylmethoxy)carbonyl]-Lleucyl- $N$-[(1S)-1-formyl-3-methylbutyl]-L-leucinamide) was from Tocris Bioscience.

Neuronal culture. Culture dishes, glass coverslips, or 24- or 96-well dishes were coated overnight with $20 \mu \mathrm{g} / \mathrm{ml} \mathrm{laminin} \mathrm{or} 4 \mu \mathrm{g} / \mathrm{ml} \mathrm{recom-}$ binant L1-Fc mixed with $8 \mu \mathrm{g} / \mathrm{ml} \mathrm{Fc}$ in PBS. Explants of embryonic day 7 (E7) and E13 DRGs, E7 temporal retina, and E7 sympathetic ganglia were dissected from chick embryos, and DRGs were removed from E15 mouse embryos, according to procedures approved by the University of Minnesota Institutional Animal Care and Use Committee. Neural tissues were cultured on experimental substrates in F-12 with B27 additives and buffered to pH 7.4 with 10 mM HEPES. Neurotrophins, NGF or NT-3, were added to cultures, as noted. Neural tissues were cultured overnight in a humidified incubator at $37^{\circ} \mathrm{C}$.

Neuronal transfection. E7 chick DRGs were dissected and dissociated with $0.2 \%$ bacto-trypsin in calcium- and magnesium-free (CMF) PBS for 10 min and then rinsed with F-12H containing 10\% serum. Approximately $2 \times 10^{6}$ cells were transfected with $3 \mu$ g of a plasmid encoding the fluorescent F-actin probe, green fluorescent protein (GFP)-utrophin calponin homology domain (UtrCH) kindly provided by Dr. W. M. Bement (University of Wisconsin, Madison, WI) (Burkel et al., 2007), using the G-13 program of the Amaxa Biosystems Nucleofector. Cells were then rinsed with F-12H and cultured overnight in F-12 with B27 additives on video dishes coated with poly-D-lysine, nitrocellulose, and $\mathrm{L} 1$.

Axon elongation assay. The effect of protein synthesis inhibitors on axon elongation was determined by time-lapse microscopy of axon elongation by DRG or retinal explants cultured in F-12 with B27 (and 10 ng/ml NGF for DRGs) on laminin- or L1-coated 96-well dishes. A dish was placed on the warmed stage of a Nikon inverted microscope, and a microscope field of axons was chosen. Cycloheximide (CHI) or anisomycin (or PBS for control) was added at $20 \mu \mathrm{M}$, and time-lapse images were collected at $2-5 \mathrm{~min}$ intervals for $2-5 \mathrm{~h}$. Axon elongation rates of sample populations were determined, using MetaMorph software (Molecular Devices), to measure the distance a growth cone migrated in 5-10 min intervals over a $3-5 \mathrm{~h}$ period.

Growth cone collapse assay. Collapse assays were conducted in 24- or 96-well dishes. Explants were cultured overnight. NGF, $10 \mathrm{ng} / \mathrm{ml}$, was added to cultures of DRGs or sympathetic ganglia. $\mathrm{CHI}$ or anisomycin was added in PBS at $20 \mu \mathrm{M}$ for $15 \mathrm{~min}$. Control dishes received PBS. After $15 \mathrm{~min}$ guidance molecules, Sema3A $(0.5 \mu \mathrm{g} / \mathrm{ml})$, ephrin-A2 $(1 \mu \mathrm{m} / \mathrm{ml})$, or slit-3 $(1 \mu \mathrm{g} / \mathrm{ml})$ were added for $30 \mathrm{~min}$ in the continued presence of protein synthesis inhibitors. Control dishes received PBS. After $30 \mathrm{~min}$, explants were fixed with $0.5 \%$ glutaraldehyde in $\mathrm{PBS}$ for $20 \mathrm{~min}$ at $37^{\circ} \mathrm{C}$. After rinsing in PBS, the wells were visualized with a $20 \times$ phase-contrast objective, and growth cones were counted as collapsed if they had one or no filopodia.

Growth cone spreading assay. DRG explants were cultured overnight in 96-well dishes. A dish was placed on a warmed stage of an inverted microscope, a field of axons was chosen, and images were collected once per minute for $15 \mathrm{~min}$. Then, $40 \mathrm{ng} / \mathrm{ml} \mathrm{NGF}$ or NT-3 was added, and images of the same field were collected every minute for $30 \mathrm{~min}$. Growth cone spreading was measured using MetaMorph software to outline the borders of growth cones and determine the enclosed areas.

Growth cone turning assay. DRG explants were cultured overnight in F-12 with B27 on laminin-coated coverslips glued over a hole in the bottom of a culture dish. Micropipette tips were dipped in a $1 \%$ nitrocellulose solution and dried. After drying, a tip was dipped several times in a solution of $1 \mu \mathrm{g} / \mathrm{ml}$ NGF or BSA in PBS. The micropipette was mounted on a micromanipulator. A culture dish was placed on the warmed microscope stage, and the micropipette tip was positioned 50 $\mu \mathrm{m}$ from a growth cone at a $45^{\circ}$ angle to the direction of axon elongation. Images were acquired at $30 \mathrm{~s}$ intervals for $15 \mathrm{~min}$ before and $45 \mathrm{~min}$ after introducing the micropipette tip. $\mathrm{CHI}$ was added to some dishes at the beginning of image acquisition. Growth cone turning angles were determined as the change in direction of growth cone migration between the beginning and end of the image acquisition period (Ming et al., 1997).

Compartmented cultures. Compartmented cultures were made by putting an E7 DRG explant with attached peripheral root on a substrate and adhering a $5 \mathrm{~mm}$ glass cloning cylinder to the substrate with silicone grease, so the DRG was within the lumen and the peripheral root extended under the $1 \mathrm{~mm}$ cylinder wall with its terminus outside the wall. This created two compartments and allowed us to expose the DRG and the peripheral root to different media. For chemotaxis experiments, a 3 $\mathrm{mg} / \mathrm{ml}$ collagen gel was created in the outside compartment, following the instructions of the manufacturer (PurCol; Inamed). Affi-Gel BlueGel chromatography beads were soaked in $1 \mu \mathrm{g} / \mathrm{ml}$ NGF or BSA in PBS for $1 \mathrm{~h}$, rinsed in PBS, and then placed in the collagen gel near the peripheral nerve root with an NGF bead on one side and a BSA bead on the other side of the root.

Immunocytochemistry. For immunocytochemistry, explants cultured on laminin- or L1-coated coverslips were fixed with warmed $4 \%$ paraformaldehyde in PBS with 5\% sucrose at $\mathrm{pH} 7.4$ for $30 \mathrm{~min}$. After rinsing, explants were treated $15 \mathrm{~min}$ with $0.1 \mathrm{M}$ glycine in PBS and extracted with $0.1 \%$ Triton X-100 (TX-100) in PBS with 2\% goat serum and 1\% BSA for $1 \mathrm{~h}$. Coverslips were incubated with the primary antibodies diluted in PBS containing 1\% BSA for $1 \mathrm{~h}$. Primary antibody dilutions were 1:100 for anti-RhoA and anti-eIF-4EBP-P, and anti- $\beta$-actin was used, per instructions from Dr. Ervasti (Prins et al., 2008). For labeling F-actin, Alexa Fluor 488 -phalloidin was applied at $2.5 \mu \mathrm{l} / 100 \mu \mathrm{l}$ mixed with the primary antibodies. The coverslips were rinsed and then incubated in $0.1 \%$ TX-100 in PBS with 2\% goat serum and 1\% BSA for $1 \mathrm{~h}$. Then, Alexa Fluor 568 goat anti-rabbit or anti-mouse antibodies at 1:1000 dilution were applied in PBS with 1\% BSA for $1 \mathrm{~h}$. After rinsing, the coverslips were incubated in $0.1 \%$ TX-100 in PBS with $2 \%$ goat serum and $1 \%$ BSA for $30 \mathrm{~min}$, rinsed, and mounted in anti-fading medium.

Nascent protein synthesis. To measure effects of protein synthesis inhibitors CHI and anisomycin on cultured DRG neurons, we used Click-iT reagents from Invitrogen. E7 DRGs were dissociated with $0.2 \%$ bacto-trypsin in CMF-PBS for $15 \mathrm{~min}$, rinsed, and plated on poly-Dlysine- and laminin-coated glass coverslips in DMEM with B27 additives and $10 \mathrm{ng} / \mathrm{ml} \mathrm{NGF}$. After overnight culture, the dishes were rinsed twice with warmed PBS and incubated in methionine-free DMEM for $45 \mathrm{~min}$. During the last $15 \mathrm{~min}$ of this period, $20 \mu \mathrm{M}$ CHI or anisomycin or control buffer were added to experimental dishes. Then, the medium was replaced with methionine-free DMEM to which $50 \mu \mathrm{M}$ of the methionine analog L-azidohomoalanine (AHA) (catalog \#C10102; Invitrogen) was added. AHA was omitted from some dishes as a negative control. The dishes were returned to the incubator for $60 \mathrm{~min}$ for incorporation of the AHA into nascent proteins with or without protein synthesis inhibitors. After $60 \mathrm{~min}$, the dishes were rinsed twice and incubated $30 \mathrm{~min}$ in methionine-free DMEM with or without protein synthesis inhibitors. The cultures were fixed with $2 \%$ paraformaldehyde and $5 \%$ sucrose in PBS for $30 \mathrm{~min}$ and then rinsed and incubated in PBS with $0.1 \mathrm{M}$ glycine for $15 \mathrm{~min}$. The coverslips were then drained and placed on Parafilm in a humidified $150 \mathrm{~mm}$ Petri dish. Using the nomenclature of the Click-iT reagent kit (catalog \#C3337; Invitrogen), the carboxytetramethylrhodamine alkyne (TAMRA) reagent was prepared by rapidly mixing $150 \mu \mathrm{l}$ of the Step 1 solution with $120 \mu \mathrm{l}$ of distilled water, then $15 \mu \mathrm{l}$ of Component $\mathrm{C}$ was added with $5 \mathrm{~s}$ vortexing, followed by $15 \mu \mathrm{l}$ of Step III solution with $5 \mathrm{~s}$ vortexing. Fifty microliters of this solution was applied to each coverslip, followed by $5 \mu$ l of the Step 2 solution, which was rapidly mixed with the solution on each coverslip. The coverslips were then incubated $30 \mathrm{~min}$ in the dark. Then, the coverslips were drained, rinsed twice with distilled water, then twice with methanol for $15 \mathrm{~min}$, 
before being returned to distilled water, and finally mounted on glass slides in anti-fading medium.

To measure the effects of NGF and Sema3A on protein synthesis in DRG neurons, we used the Click-iT reagents as described above. Dissociated DRG neurons were cultured overnight on poly-D-lysine- and laminin-coated coverslips in DMEM and B27 additives with $0.1 \mathrm{ng} / \mathrm{ml}$ NGF. After rinsing and 45 min incubation in methionine-free DMEM, the medium was replaced with methionine-free DMEM containing 50 $\mu \mathrm{M}$ AHA and $40 \mathrm{ng} / \mathrm{ml} \mathrm{NGF,} 1 \mu \mathrm{g} / \mathrm{ml} \mathrm{Sema} 3 \mathrm{~A}$, or PBS as a control for addition of a guidance cue. Other samples were incubated in methionine-free DMEM without AHA, as a control for the TAMRA reagent procedure. After $1 \mathrm{~h}$ incubation with AHA and the guidance cues, the dishes were rinsed twice and incubated in methionine-free DMEM for $30 \mathrm{~min}$, followed by fixation and incubation with the TAMRA reagents, as described above.

Quantitative fluorescence determinations. A Spot digital camera mounted on an Olympus XC-70 inverted microscope was used to acquire all images for quantitative fluorescence measurements. In any one experiment, all coverslips with explants or cells were fixed and processed together. For collection of fluorescence images, all images for one experiment were acquired in a single session. Parameters of time interval and gain setting on the digital SPOT camera were adjusted so the brightest areas did not reach saturation, and the same gain and time interval was used to capture all images of any particular staining. All analysis of image intensities was conducted from a similar region at the center of the microscope field.

MetaMorph software (Molecular Devices) was used for all image analysis. Software tools were used to determine fluorescence intensity along axons, using a line-scan tool, within growth cones, using a line tool to outline the terminal $25 \mu \mathrm{m}$ of each distal axon and growth cone, and a square-shaped tool placed within the center of neuronal somata. After acquisition of each fluorescent neuronal image, a measure of background fluorescence was acquired by moving the software tool slightly outside the boundary of the neuron. The background fluorescence intensity value was subtracted from the fluorescence intensity value of the accompanying neuronal measurement.

Effects of NGF and Sema3A on phospho-eIF-4EBP content of distal axons. E7 DRG explants were cultured overnight on laminin-coated coverslips. NGF at $40 \mathrm{ng} / \mathrm{ml}, 1 \mu \mathrm{g} / \mathrm{ml} \mathrm{Sema3A}$, or PBS was added for $15 \mathrm{~min}$, and then the cultures were fixed and processed for immunofluorescence staining, as described above. For measuring anti-eIF-4EBP-P staining, images of immunofluorescence staining of a sample population of distal axons and growth cones were acquired using a $60 \times$ oil-immersion objective. The line-scan tool was used to determine mean fluorescence intensity of a line, 2 pixels wide, extending proximally $15 \mu \mathrm{m}$ from the $\mathrm{C}$ domain of a growth cone into the axon.

Effects of NGF, Sema3A, and protein synthesis inhibitors on nascent protein synthesis. Cultures of dissociated E7 DRG cells were treated with NGF, Sema3A, cycloheximide, or anisomycin and then fixed and incubated with AHA and the Click-iT reagents, as described in detail above. Fluorescence images of labeled neurons were acquired with a $20 \times$ objective, and mean intensity of axonal and perikaryon carboxytetramethylrhodamine fluorescence was quantified as described above.

Effects of NGF and Sema3A on $\beta$-actin and RhoA content, respectively, of $D R G$ growth cones. E7 DRG explants were cultured overnight on laminincoated coverslips. Twenty micromolar CHI or PBS was added to cultures for $15 \mathrm{~min}$, and then $40 \mathrm{ng} / \mathrm{ml} \mathrm{NGF}, 1 \mu \mathrm{g} / \mathrm{ml} \mathrm{Sema} 3 \mathrm{~A}$, or PBS was added to a culture dish for $15 \mathrm{~min}$ in the continued presence of $\mathrm{CHI}$ or PBS. The cultures were fixed and processed for immunofluorescence staining with anti-RhoA (Sema3A-treated and controls) or anti- $\beta$-actin (NGF-treated and controls). Images of immunofluorescence staining of a sample population of growth cones were acquired using a $60 \times$ oil-immersion objective. To measure growth cone content of RhoA or $\beta$-actin, the boundary of the distal $25 \mu \mathrm{m}$ of each growth cone and distal axon was outlined with an outline tool, and the mean integrated pixel intensity of anti-RhoA or anti- $\beta$-actin staining was determined.

Effects of Sema3A and ephrin-A2 on F-actin distribution in DRG and retinal growth cones. For measuring effects of ephrin-A2 and Sema3A on F-actin content of growth cones, E7 DRGs and temporal retina explants were cultured overnight on L1-coated coverslips. Twenty micromolar $\mathrm{CHI}$ or PBS was added for $15 \mathrm{~min}$, and then $40 \mathrm{ng} / \mathrm{ml} \mathrm{NGF}$ (DRGs) or 2 $\mu \mathrm{g} / \mathrm{ml}$ ephrin-A2 (temporal retina) was added for $15 \mathrm{~min}$ in the continued presence of CHI or PBS. The cultures were fixed with $4 \%$ paraformaldehyde and 5\% sucrose for $30 \mathrm{~min}$ and then extracted with $0.1 \%$ TX-100 in PBS for 15 min. F-actin was stained by incubation with 2.5 $\mu 1 / 0.1 \mathrm{ml}$ Alexa Fluor 568-phalloidin in PBS for $60 \mathrm{~min}$. After rinsing, the coverslips were mounted in anti-fading medium. Images of sample populations of growth cones were acquired with a $60 \times$ oil-immersion objective. Using the line-scan tool of MetaMorph, phalloidin fluorescence was determined along a 2-pixel-wide by $6 \mu \mathrm{m}$ line backward from the center of the growth cone leading margin.

Effects of NGF on F-actin content of DRG growth cones. E7 DRG explants were cultured overnight on L1-coated coverslips. Twenty micromolar CHI or PBS was added to cultures for $15 \mathrm{~min}$, and then $40 \mathrm{ng} / \mathrm{ml}$ NGF was added for $15 \mathrm{~min}$ in the continued presence of CHI or PBS. The cultures were fixed with $4 \%$ paraformaldehyde and 5\% sucrose for 30 min and then extracted with $0.1 \%$ TX-100 in PBS for 15 min. F-actin was stained by incubation with $2.5 \mu \mathrm{l} / 0.1 \mathrm{ml}$ Alexa Fluor 568 -phalloidin in PBS for $60 \mathrm{~min}$. After rinsing, the coverslips were mounted in anti-fading medium. Images of growth cones were acquired with a $60 \times$ oilimmersion objective. To measure F-actin content, the boundary of each growth cone was outlined with the outline tool, and the mean pixel intensity and integrated pixel intensities of F-actin staining were determined for each growth cone.

Effects of NGF gradient on GFP-UtrCH distribution in DRG growth cones. Immediately after placing a video dish with GFP-UtrCHtransfected neurons on a warmed microscope stage, $20 \mu \mathrm{M}$ cycloheximide or the same volume of control media was added for $15 \mathrm{~min}$. A transfected growth cone was identified, and a fluorescent image was taken. An NGF- or BSA-coated micropipette was brought to one side of the growth cone, and after, $2 \mathrm{~min}$, another image was acquired using the same exposure and gain settings. Using MetaMorph software, a 15-pixelthick line was drawn across the growth cone (perpendicular to its neurite axis) at the two time points before and after applying the NGF gradient. The "line-scan" function was used to obtain fluorescence intensity measurements for each point along the line across the growth cone. Ten growth cones for the control and cycloheximide conditions were used in the analysis.

Statistical analysis. Parameters of population values are reported as mean \pm SEM. All statistical analysis was by unpaired Student's $t$ test or Mann-Whitney $U$ test.

\section{Results}

NGF and Sema3A activate protein synthesis in DRG neurons It is reported that guidance cues trigger inactivation of the translation repressor elF-4EBP1 in distal axons (Campbell and Holt, 2001; Li et al., 2004; Cox et al., 2008). Inactivation of e1F-4EBP1 by phosphorylation releases elongation factor elF-4E to initiate mRNA translation. We used phospho-specific antibodies to ask whether the guidance cues NGF and Sema3A induce elF-4EBP1 phosphorylation in axons extended from E7 chick DRG. DRG explants were cultured overnight and exposed to NGF or Sema3A for 15 min before fixation and staining with anti-elF-4EBP1-P (Fig. $1 a-c$ ). Figure $1 d$ shows analysis of mean anti-elF-4EBP-P staining of a line scanned from the center of each growth cone proximally for $15 \mu \mathrm{m}$ in the axon. The mean staining intensity for elF-4EBP1-P was significantly greater in distal axons of both NGF- and Sema3A-treated DRG cultures than in axons of untreated DRGs. Thus, like previous reports, signaling triggered by NGF and Sema3A inhibits a repressor of mRNA translation in distal axons of DRG neurons.

The inactivation of elF-4EBP1 and activation of elongation initiation factor $4 \mathrm{E}$ are associated with increased protein synthesis in response to growth factors and guidance cues (Campbell and Holt, 2001; Takei et al., 2001; Li et al., 2004). We investigated whether protein synthesis in DRG neurons is altered by NGF and 

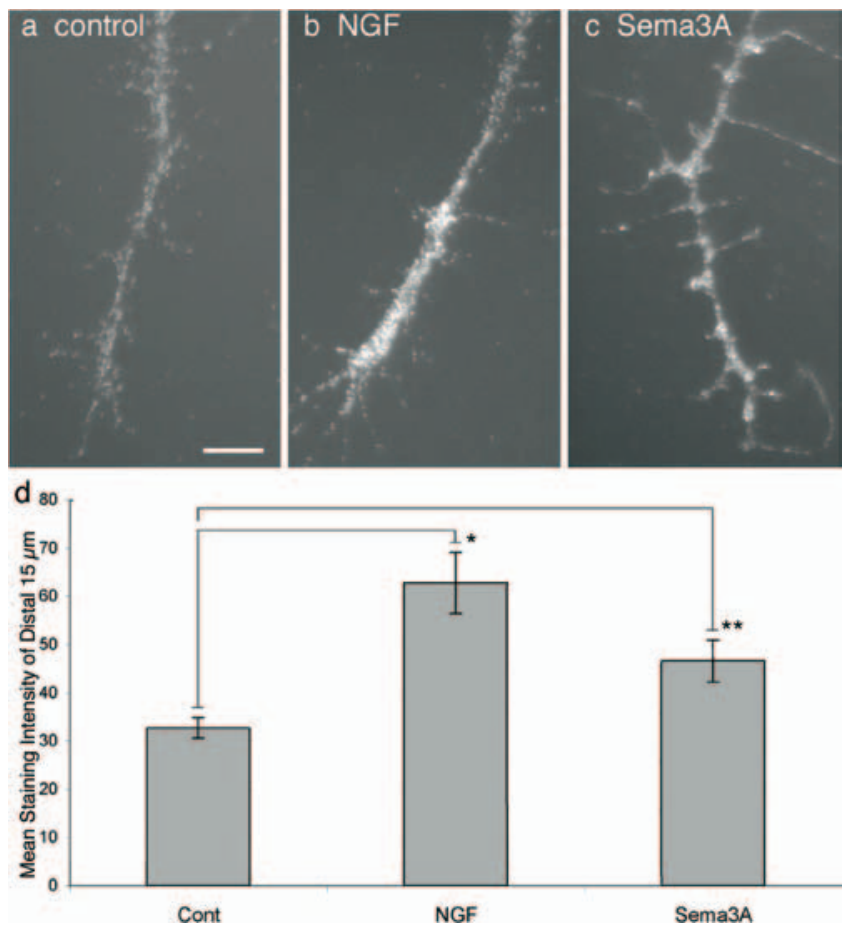

Figure 1. NGF and Sema3A increase phosphorylation of elF-4EBP1. Distal axons of chick E7 DRG neurons stained with anti-phospho-elF-4EBP1 in control medium (a) or after 15 min stimulation with $40 \mathrm{ng} / \mathrm{ml} \mathrm{NGF}(\boldsymbol{b})$ or $0.5 \mu \mathrm{g} / \mathrm{ml} \mathrm{Sema3A}$ (c). d shows mean staining intensity along a 2-pixel-wide line and 15- $\mu \mathrm{m}$-long starting at the growth cone $C$ domain and into the distal axon. ${ }^{*} p<0.005,{ }^{* *} p<0.01$. Scale bar, $10 \mu \mathrm{m}$. Cont, Control.

Sema3A. To detect nascent proteins, we used the nonradioactive reagent $\mathrm{AHA}$, a methionine analog that is incorporated into proteins instead of methionine and is detected by reaction of the azido-modified protein with a fluorescent alkyne (for details, see Materials and Methods). Overnight cultures of dissociated E7 DRGs were exposed to NGF or Sema3A in AHA-containing media for $60 \mathrm{~min}$ before fixation and reaction with the fluorescent alkyne. To control for the labeling procedures, some samples were not given AHA, and, to control for the addition of guidance cues, other samples were given AHA but neither NGF nor Sema3A. As shown in Figure $2 a-e$, the mean staining intensity for nascent proteins in both cell bodies and distal axons was increased $60 \%$ by NGF addition compared with cultures not treated with NGF. After addition of Sema3A, the nascent protein amounts were also elevated from the levels in untreated control neurons. Because this experiment involved one time point, we make no conclusion about effects of NGF or Sema3A on rates of nascent protein synthesis or degradation. Because of the global presentation of ligands and the duration of treatment, we infer nothing about the location of nascent protein synthesis. However, our results indicate that NGF and Sema3A stimulate increased amounts of nascent proteins in cell bodies and axons of DRG neurons. Thus, like previous reports, we found that guidance cues increase nascent proteins in neurons (Zhang et al., 1999, 2001; Campbell and Holt, 2001).

\section{DRG axonal elongation is inhibited by global treatment with protein synthesis inhibitors but not by inhibiting protein synthesis in distal axons only}

Before assessing the effects of inhibiting protein synthesis on responses to guidance cues, we showed that $\mathrm{CHI}$, which inhibits peptide chain elongation, and anisomycin, which inhibits pep- tide bond formation, are effective inhibitors of chick neuronal protein synthesis. These drugs were used previously to inhibit protein synthesis in chick neurons (Ludueña, 1973; Oppenheim et al., 1990; Blackmore and Letourneau, 2007). To measure the effects of CHI and anisomycin, we used the same Click-iT reagents that we used to determine the effects of NGF and Sema3A on nascent protein synthesis. After washing out methioninecontaining DMEM medium, DRG cells were incubated for $1 \mathrm{~h}$ with $50 \mathrm{~mm}$ AHA with or without $20 \mu \mathrm{M} \mathrm{CHI}$ or anisomycin. As shown in Figure $2 f-i$ and quantitated in $j$, CHI- and anisomycintreated neurons were as weakly labeled as control neurons that were not incubated with the methionine analog AHA but only with the fluorescent alkyne reagents. Thus, we could not detect protein synthesis in DRG neurons treated with $\mathrm{CHI}$ or anisomycin.

Because it was reported previously that global application of protein synthesis inhibitors did not inhibit axonal extension during a $1 \mathrm{~h}$ period (Campbell and Holt, 2001), we investigated axonal elongation by DRG and retinal neurons in the global presence of protein synthesis inhibitors. Explants of E7 DRGs and temporal retina were grown in dishes coated with laminin or the cell adhesion molecule L1. CHI, anisomycin, or the drug vehicle was added, and rates of axonal elongation were calculated after time-lapse imaging. The mean elongation rate for untreated DRG or retinal axons did not change over $4 \mathrm{~h}$ of recording, although the elongation rate for DRG axons was significantly faster on laminin than on $\mathrm{L} 1(130 \pm 16$ vs $41 \pm 6 \mu \mathrm{m} / \mathrm{h}$, respectively). During the first hour of treatment with $20 \mu \mathrm{M}$ CHI or anisomycin, the axonal elongation rate of treated DRG or retinal neurons was nearly equal to that of control, untreated neurons (Table 1 , Fig. $3 a$ ). During the second hour, axonal growth rates began to slow in the presence of protein synthesis inhibitors (Table 1, Fig. $3 a$ ). Some growth cones became smaller and less motile, and, on laminin, some axons retracted. On L1, axonal retraction during the second hour of treatment was less frequent than on laminin, but the rate of axon elongation still slowed (Table 1). Continuing after $2 \mathrm{~h}$ of protein synthesis inhibition, nearly all axons retracted or became quiescent (Fig. 3b) (supplemental Fig. S1, available at www.jneurosci.org as supplemental material).

We asked whether concurrent inhibition of proteolysis might extend the time that axons elongate in the presence of protein synthesis inhibitors. We added MG-132, an inhibitor of proteosome activity used previously with neurons (Lee and Goldberg 1996; Tursun et al., 2005), to some wells that received CHI. MG132 alone did not reduce axon elongation over $4 \mathrm{~h}$ (Fig. $3 b$ ). When $\mathrm{CHI}$ was combined with MG-132, fewer axons retracted during hours 2-5 in CHI plus MG-132 than in wells treated with $\mathrm{CHI}$ alone, but axonal growth had still stopped in CHI plus MG132 by $4-5 \mathrm{~h}$ (Fig. $3 b$ ). Thus, global inhibition of protein synthesis does not significantly inhibit axonal elongation during the first hour of treatment, but, during the second hour, axonal growth slowed and axons began to retract or lose growth cone activity. Concurrent inhibition of protein degradation prolonged the period during which axons could elongate in the absence of protein synthesis.

Previously, compartmented chambers were used to show that protein synthesis in distal axons is not required for axonal elongation (Eng et al., 1999; Blackmore and Letourneau, 2007). We devised a compartmented dish to investigate whether distal protein synthesis is required for DRG axon elongation. An E7, DRG with the attached peripheral root was placed in the lumen of a 5 -mm-diameter glass cloning cylinder, which was stuck to the substrate with silicon grease. The distal portion of the peripheral 
root was extended under the cylinder wall, so the end of the root was outside the cylinder. We determined that the inside of the cloning cylinder and the dish outside the cylinder were separate compartments by showing that blue dye placed in one compartment did not diffuse into the other compartment over $24 \mathrm{~h}$. In addition, different heights of the liquid medium could be maintained in the two compartments. When control medium was in the distal compartment, Schwann cells migrated with axons that extended from the end of the peripheral nerve (Fig. 3c). After $24 \mathrm{~h}$, axons and Schwann cells had extended hundreds of micrometers from the nerve root. If $20 \mu \mathrm{M} \mathrm{CHI}$ was in the distal axon compartment, axons still elongated for many hours (Fig. 3d), but Schwann cells did not leave the nerve roots (Fig. 3, compare $c, d)$. Because of the separation of the compartments, axons and Schwann cells migrated from the explants in the perikaryon compartment of dishes with $\mathrm{CHI}$ in the distal axon compartment (Fig. $3 e, f$ are similar, despite $\mathrm{CHI}$ in the axon compartment). Axonal growth rates were comparable in untreated $(144 \pm 13 \mu \mathrm{m} / \mathrm{h})$ or CHI-treated $(140 \pm 14 \mu \mathrm{m} / \mathrm{h})$ distal axonal compartments. Thus, although axonal growth from DRG explants stops after $1 \mathrm{~h}$ of global inhibition of protein synthesis, protein synthesis is not required in distal axons for DRG axonal growth for $>24$ h.

\section{Induction of growth cone collapse by repulsive cues does not require protein synthesis}

Growth cone collapse assays were conducted with E7 and E13 DRG explants that were exposed to Sema3A, E8 sympathetic chain ganglia exposed to Sema6A, and E7 temporal retinal explants exposed to negative cues, ephrin-A2 and slit-3 (Table 2, Fig. 4). Explants were cultured $24 \mathrm{~h}$ in laminin-coated wells, and then $20 \mu \mathrm{M} \mathrm{CHI}$ or anisomycin or control vehicle were added for $15 \mathrm{~min}$ before adding Sema3A to DRG cultures, or ephrin-A2 or slit-3 to temporal retinal cultures for $30 \mathrm{~min}$. As illustrated in Figure 4 and presented in Table 2, the low collapse rates of untreated growth cones and the high growth cone collapse induced by these repulsive guidance cues were not different in the presence of CHI than results from explants treated with the drug vehicle (MannWhitney $U$ test). Without repulsive cues, the growth cone collapse frequency did not exceed 16\%, despite the presence of protein synthesis inhibitors for $45 \mathrm{~min}$. After adding repulsive cues, the collapse frequency was $>80 \%$ for Sema3A, Sema6A, and ephrin-A2 and $>60 \%$ for slit-3 with or
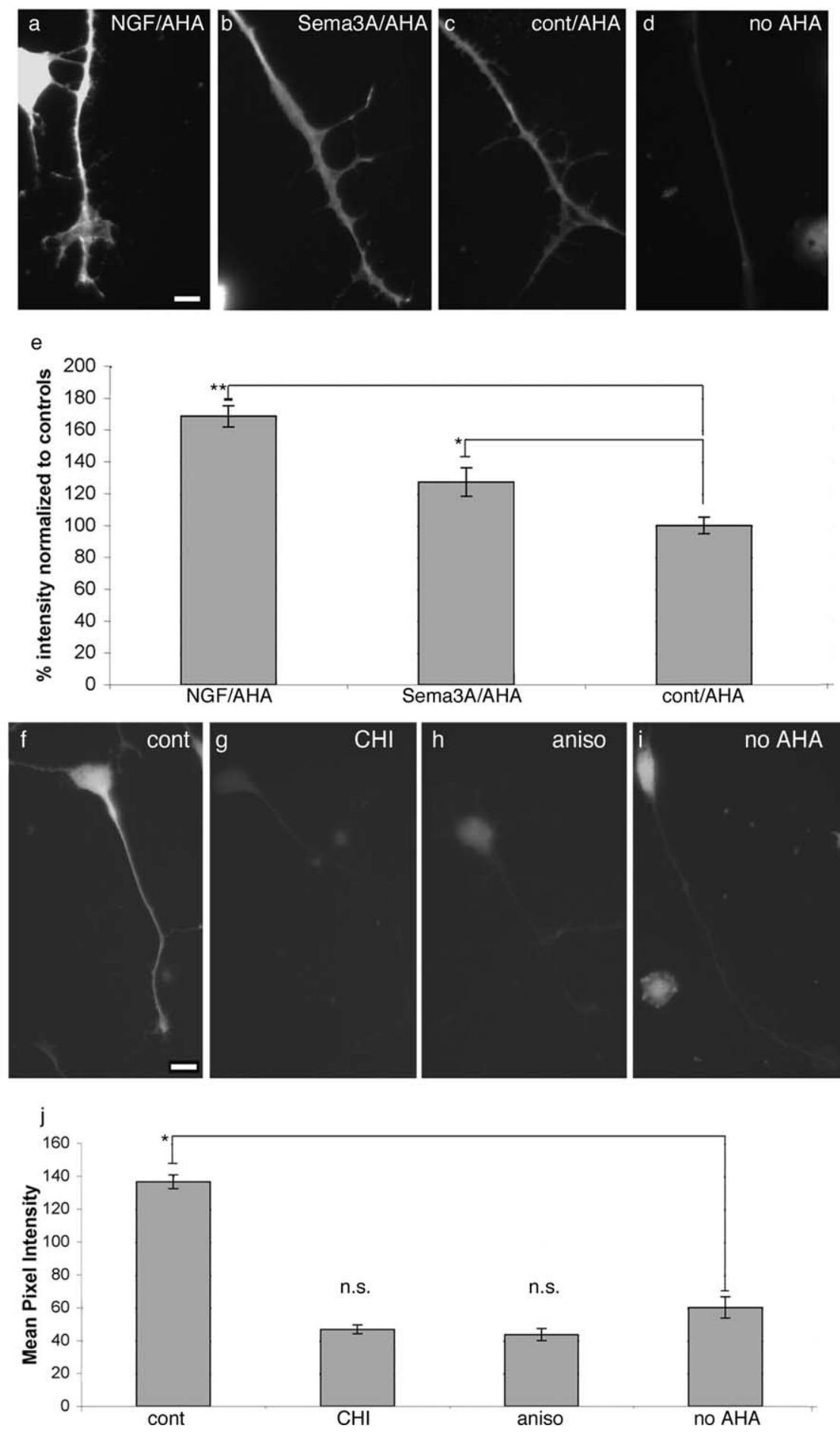

Figure 2. Nascent protein synthesis in E7 DRG neurons. The methionine analog AHA in methionine-free DMEM was added to dissociated cells treated with $40 \mathrm{ng} / \mathrm{mINGF}(\boldsymbol{a}), 0.5 \mu \mathrm{g} / \mathrm{ml} \mathrm{Sema3A}$ (b), or control medium (cont) (c) for $60 \mathrm{~min}$. Cells in d received no AHA. Cells were fixed and incubated with fluorescent alkyne to label the AHA incorporated into nascent proteins. $\boldsymbol{e}$, Mean staining intensity of NGF- and Sema3A-treated distal axon segments relative to unstimulated neurons. Mean \pm SEM. ${ }^{*} p<0.05$, ${ }^{* *} p<0.001$. $\mathbf{f}-\mathbf{i}$, The protein synthesis inhibitors $\mathrm{CH}$ and anisomycin (aniso) inhibit protein synthesis. Dissociated DRG cells cultured overnight in medium with $10 \mathrm{ng} / \mathrm{ml} \mathrm{NGF}$ were incubated $60 \mathrm{~min}$ in methionine-free DMEM with AHA $(\boldsymbol{f})$ or with addition of $20 \mu \mathrm{M}$ CHI $(\boldsymbol{g})$ or $20 \mu \mathrm{m}$ anisomycin $(\boldsymbol{h})$. Cells in $\boldsymbol{i}$ received no AHA. Fluorescent alkyne labeling of the CHI- and anisomycintreated neurons and axons $(\boldsymbol{f}, \boldsymbol{g})$ was as weak as labeling of cells that were not incubated with AHA $(\boldsymbol{h})$. Scale bars: $\boldsymbol{a}($ for $\boldsymbol{a}-\boldsymbol{d}), 10$ $\mu \mathrm{m} ; \boldsymbol{f}($ for $\boldsymbol{f}-\boldsymbol{i}), 15 \mu \mathrm{m}$. $\boldsymbol{j}$, Mean staining intensity of distal axons. Mean $\pm \mathrm{SEM} .{ }^{*} p<0.00001$.

without protein synthesis inhibitors. In addition to studies with chick DRGs, we investigated whether protein synthesis was required for growth cones of embryonic mouse DRG neurons to respond to Sema3A. DRGs were explanted from E15 mice and 
Table 1. Effects of protein synthesis inhibitors on rate of axonal elongation

\begin{tabular}{|c|c|c|c|c|}
\hline Neuron & Inhibitor & Substrate & $0-1 \mathrm{~h}$ (\% control rate) & $1-2 \mathrm{~h}$ (\% control rate) \\
\hline \multirow[t]{3}{*}{ DRG } & Cycloheximide & Laminin & $98 \pm 9$ & $54 \pm 12$ \\
\hline & Anisomycin & Laminin & $88 \pm 14$ & $39 \pm 11$ \\
\hline & Puromycin & Laminin & $75 \pm 10$ & $26 \pm 14$ \\
\hline \multirow[t]{2}{*}{ DRG } & Cycloheximide & L1 & $76 \pm 15$ & $34 \pm 12$ \\
\hline & Anisomycin & L1 & $96 \pm 13$ & $25 \pm 9$ \\
\hline \multirow[t]{2}{*}{ Retina } & Cycloheximide & L1 & $83 \pm 11$ & $59 \pm 9$ \\
\hline & Anisomycin & L1 & $84 \pm 8$ & $67 \pm 9$ \\
\hline
\end{tabular}

E7 DRG or temporal retina explants were cultured in laminin- or L1-coated wells in F-12, B27 with $10 \mathrm{ng} / \mathrm{ml} \mathrm{NGF}$ added to DRG cultures. After $24 \mathrm{~h} 20 \mu \mathrm{m}$ CHI anisomycin or puromycin, or the drug vehicle was added to a well of a dish on a warm microscope stage, and video images were collected at 2-5 min intervals for $2 \mathrm{~h}$ or more. Axon elongation rates were determined using Metamorph software to measure axon elongation at 5-10 min intervals. Average \pm SEM axon elongation in drug-treated cultures is expressed as percentage of the elongation rate in vehicle-treated control cultures.

cultured $24 \mathrm{~h}$ on laminin. Cultures were treated for $15 \mathrm{~min}$ with $\mathrm{CHI}$ or the vehicle for $15 \mathrm{~min}$, before adding Sema3A. As shown in Figure $4 m-p$ and Table 2, CHI treatment did not inhibit the collapse response of mouse DRG growth cones to Sema3A. Some E7 DRG explants were cultured $8 \mathrm{~d}$ before treatment. Many growing axons with active growth cones were present with a mean growth rate of $64 \pm 5 \mu \mathrm{m} / \mathrm{h}(n=22)$, and the growth rate did not change, when $20 \mu \mathrm{M} \mathrm{CHI}$ was added for $30 \mathrm{~min}(69 \pm 4$ $\mu \mathrm{m} / \mathrm{h}, n=22)$. When $1 \mu \mathrm{g} / \mathrm{ml} \mathrm{Sema3A}$ was added to the CHItreated dishes, 95\% growth cones rapidly collapsed. Thus, protein synthesis is not required for growth cone collapse by several neuronal types in response to several negative cues.

We tested the effects of inhibiting protein synthesis on retinal growth cone responses to surface-bound ephrin-A2. Contact with $6 \mu \mathrm{m}$ ephrin-A2-coated beads induced 90\% of temporal retinal growth cones to collapse or turn away from the beads $(n=$ 20) (Weinl et al. 2005), whereas contacts with BSA-coated beads induced no turning or collapse $(n=8)$. In the presence of $\mathrm{CHI}$ added simultaneously with beads to E7 temporal retinal explants, growth cones did not collapse after contact with BSA-coated beads $(n=9)$, whereas $95 \%$ of CHI-treated growth cones $(n=$ 23) collapsed or turned away after contacting ephrin-A2 beads (Fig. 4q-v). These results, consistent with responses to soluble repulsive cues, indicate that protein synthesis is not required for responses to repulsive guidance cues.

\section{The loss of F-actin induced by repulsive cues does not require protein synthesis}

Downstream signaling from guidance cue receptors regulates actin filament dynamics via Rho GTPases (Wahl et al., 2000; Hu et al., 2001; Guan and Rao, 2003). Because it was reported that local RhoA synthesis is required for Sema3A-induced growth cone collapse (Wu et al., 2005), we investigated the effects of ephrin-A2 and Sema3A on actin filament organization in control and CHItreated retinal and DRG growth cones. E7 retinal and DRG explants were cultured on L1, because axonal retraction induced by repulsive cues is diminished on L1, although growth cone collapse still occurs. After 15 min pretreatment with $\mathrm{CHI}$ or the control vehicle, explants were exposed to repulsive cues for 15 min, fixed, and stained with rhodamine-phalloidin to label F-actin. Figure 5 shows images and line scans of the distribution of F-actin at the leading margins of control, ephrin-A2, or Sema3A-treated retinal and DRG growth cones, respectively, without and with CHI. Control growth cones had a peak of actin filament density at the leading margin, followed by a flat level of filament density farther back in the growth cone (Fig. 5a,e,f,j). Actin filament distribution and density in growth cones treated 30 min with CHI was identical to controls (Fig. 5b,g). In growth cones treated $15 \mathrm{~min}$ with ephrin-A2 (temporal retina) or
Sema3A (DRG), the peak in actin filament density at the leading edge was absent, and, as seen previously (Fan et al., 1993), actin filament density was significantly lower throughout the leading margin (Fig. $5 c, e, h, j)$. Growth cones of neurons treated 15 min with $\mathrm{CHI}$ and then 15 min with ephrin-A2 or Sema3A and CHI were not different from growth cones treated with repulsive cues alone (Fig. $5 d, i$ ). Thus, protein synthesis is not required for signaling downstream from repulsive cues that reduces actin filament content.

It is reported that Sema3A stimulates RhoA mRNA translation, and Sema3A increased RhoA density in rat DRG growth cones (Wu et al., 2005). We conducted similar determination of RhoA staining intensity in growth cones of DRG neurons treated with Sema3A with or without inhibiting protein synthesis. As shown in Figure $5 k-o$, we found no significant changes in mean RhoA staining intensity in DRG growth cones after Sema3A treatment in control or CHI-treated dishes. Thus, treatment of chick DRG neurons with Sema3A did not significantly change the RhoA content of growth cones.

\section{The induction of growth cone spreading, increased F-actin, and growth cone turning by NGF does not require protein synthesis}

We examined the effects of CHI on responses of E7 DRG growth cones to attractive cues NGF and NT-3. E7 DRG explants were cultured overnight in L1-coated wells in F-12 and B27 without neurotrophins. Growth cone behaviors were recorded before and after adding 40 ng/ml NGF (Fig. 6a) (supplemental Videos S1, S2, available at www.jneurosci.org as supplemental material) or NT-3 (Fig. 6b). Growth cones rapidly expanded in response to either neurotrophin. As measured in Figure 6, $c$ and $d$ (supplemental Videos S3, S4, available at www.jneurosci.org as supplemental material), this expansion response was not inhibited by 15 min pretreatment with $\mathrm{CHI}$, which remained in the media with the neurotrophins. In another experiment, we extended the $\mathrm{CHI}$ pretreatment period to $2 \mathrm{~h}$ before adding NGF. We observed that, after $2 \mathrm{~h}$ in $\mathrm{CHI}$, the spreading response of growth cones to NGF addition was absent (supplemental Fig. S2, available at www. jneurosci.org as supplemental material). Thus, chick embryo growth cones normally contain sufficient components to spread in response to neurotrophins without need for protein synthesis.

We next determined the turning response of E7 DRG growth cones toward a soluble NGF gradient. When an NGF-coated micropipette was placed near growth cones, growth cones turned toward the micropipette with a mean turning angle of $12 \pm 2.5^{\circ}$ $(n=17)$ (Fig. 6e). Using criteria of Ming et al. (1997) $\left(>5^{\circ}\right.$ is a positive turn, $-5^{\circ}$ to $+5^{\circ}$ is no turn, less than $-5^{\circ}$ is a negative turn), $65 \%$ of turns were positive, $35 \%$ did not turn, and $0 \%$ were negative turns. Turning response to a BSA-coated pipette was $-0.6 \pm 2.4^{\circ}(n=9)$, significantly different from the NGF response ( $p<0.005 ; 11 \%$ of turns were positive, $11 \%$ negative, and $78 \%$ did not turn). We then conducted assays in the presence of $\mathrm{CHI}$, which was added $15 \mathrm{~min}$ before placing the micropipette. As illustrated in Figure $6 f$, growth cone turning toward the pipette occurred with a mean turning angle of $5.4 \pm 2.1^{\circ}(n=19 ; 42 \%$ positive turns, $53 \%$ no turns, and $5 \%$ negative turns). This was statistically different from the turning angle of non-CHI treated growth cones toward NGF ( $p<0.05, t$ test). However, the turning response of $\mathrm{CHI}$-treated growth cones toward a BSA-coated 
pipette was $-1.7 \pm 2.2^{\circ}(n=11 ; 0 \%$ positive turns, $91 \%$ no turns, and $9 \%$ negative turns), which was statistically different from the $5.4 \pm 2.1^{\circ}$ turning response to an NGF micropipette $(p<0.05)$. Thus, global inhibition of protein synthesis did reduce growth cone turning toward NGF over a $45 \mathrm{~min}$ assay, although the attractive turning response was still present.

Asymmetric distribution of actin filaments is an early phase in growth cone turning toward NGF (Gallo and Letourneau, 2000). We assessed the effects of an NGF gradient on F-actin distribution in live control and CHI-treated growth cones, transfected to express a fluorescent F-actin probe, GFP-UtrCH. This probe contains the F-actin binding domain of utrophin and binds F-actin without altering the dynamics of actin-dependent events (Burkel et al., 2007). Figure 6 shows the average GFP-UtrCH intensity values along 15-pixel-wide line scans taken across the width of growth cones before and after being exposed to BSA, NGF, or NGF gradients in the presence of CHI. A shift in F-actin distribution toward the NGF source was seen in both control and CHItreated growth cones but not toward a BSA source. A quantification of the F-actin distribution across the growth cones was estimated by summing the average GFPUtrCH pixel intensities along the line scans in the growth cone halves toward the NGF source and in the halves away from the NGF source and then computing a proximal/distal ratio of the summed F-actin intensities. As a measure of change in F-actin distribution, the proximal/distal intensity ratios of images acquired $2 \mathrm{~min}$ after introducing NGF were divided by the ratios determined from images of the same growth cones acquired just before introducing NGF. For control growth cones, this ratio was $1.31 \pm 0.15 \mathrm{SE}(n=10)$, and, for CHI-treated growth cones, the ratio was $1.15 \pm .09$ SE $(n=10)$. These values were significantly different from ratios computed for growth cones exposed to a local BSA source $(0.94 \pm 0.06 \mathrm{SE})$ but were not significantly different from each other by either $t$ test or Mann-Whitney $U$ test. Thus, introduction of a local NGF source induced a shift in growth cone F-actin distribution toward the NGF source, and this was not affected by global inhibition of protein synthesis.

Growth cone spreading is correlated with increased F-actin content in NGF-treated growth cones. To examine changes in actin filament content in DRG growth cones after adding NGF, E7 DRG explants were exposed to global NGF for 15 min and then fixed and stained with rhodaminephalloidin to quantify F-actin. As shown in Figure 7, the total inte-
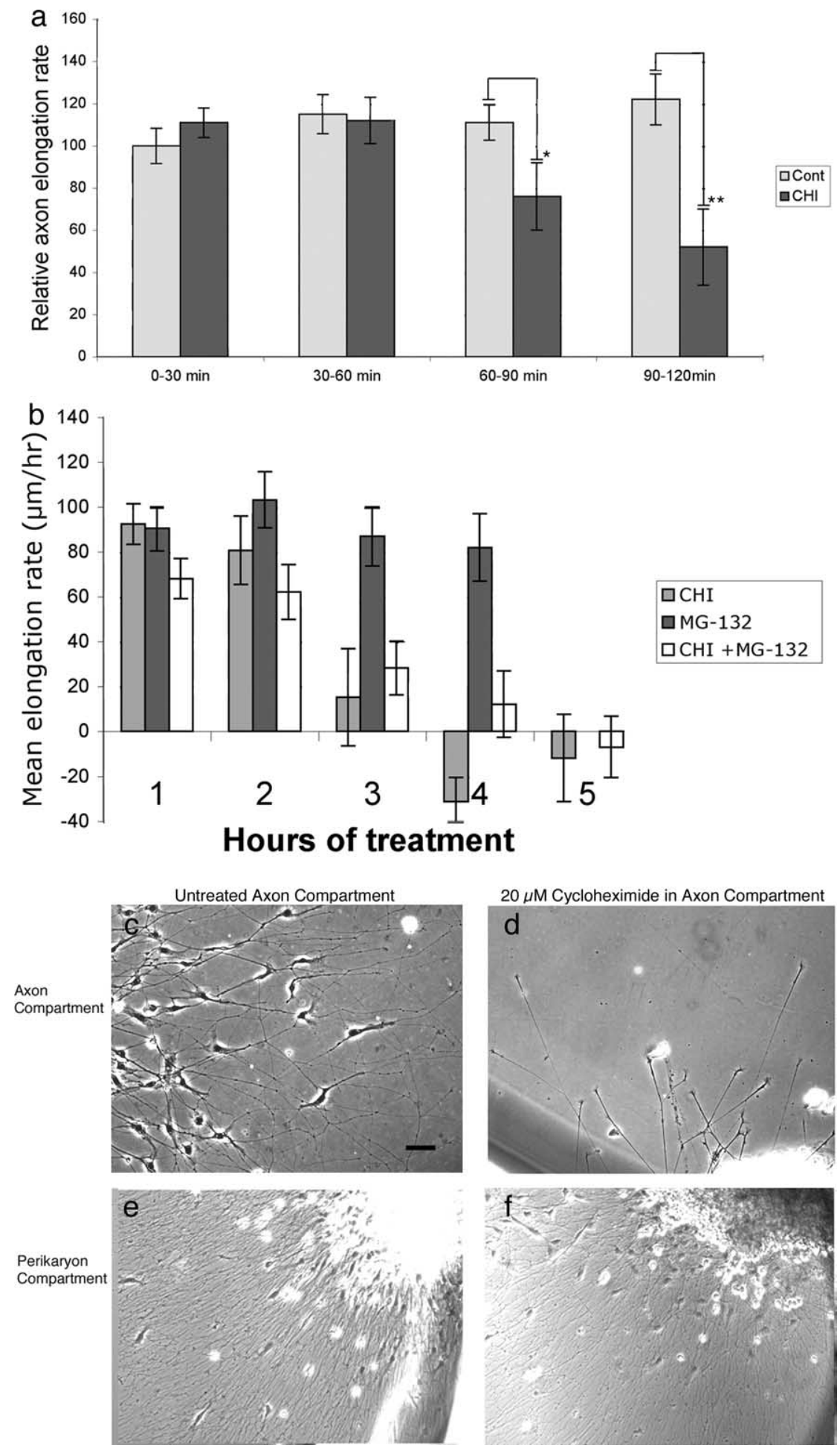

Figure 3. Effects of cycloheximide on axonal growth by E7 DRG neurons. E7 DRG explants were cultured overnight on laminin. $\boldsymbol{a}$, The effects of $20 \mu \mathrm{m}$ CHI on axon elongation rate, compared with vehicle-treated controls (Cont), over $120 \mathrm{~min}$. The inhibitory effects of $\mathrm{CH}$ are significant after $90 \mathrm{~min}$. Mean $\pm \mathrm{SEM} .{ }^{*} p<0.15,{ }^{* *} p<0.001 . \boldsymbol{b}$, The proteosome inhibitor MG-132 delays the time when axon elongation stops after inhibiting protein synthesis. Mean \pm SEM. $c-f$, DRG axon elongation in compartmented dishes. In a control axon compartment (c), axons elongate and Schwann cells migrate from the peripheral nerve root, but in a 24-h-CHItreated axon compartment $(\boldsymbol{d})$, only axons elongate from the peripheral root. In the untreated cell body compartments of both control $(\boldsymbol{e})$ and $\mathrm{CH}$-treated $(\boldsymbol{f})$ cultures, axons and Schwann cells migrate from the explants. Scale bar, $50 \mu \mathrm{m}$.

grated staining for F-actin in DRG growth cones was increased $250 \%$ at 15 min after adding NGF (Fig. $7 a, b, f$ ). This increase in F-actin was unaffected by 15 min pretreatment with $\mathrm{CHI}$ before and during NGF treatment (Fig. $7 c, d, f$ ). Thus, protein synthesis is not required 
Table 2. Effects of protein synthesis inhibitors on growth cone collapse

\begin{tabular}{|c|c|c|c|c|}
\hline Neuron type & Inhibitor & Guidance cue & $\%$ collapsed & \# GC counted \\
\hline \multirow[t]{4}{*}{ E7 Retina } & Control & Control & 7 & 237 \\
\hline & Control & ephrin-A2 & 81 & 194 \\
\hline & $\mathrm{CHI}$ & Control & 9 & 206 \\
\hline & $\mathrm{CHI}$ & ephrin-A2 & 90 & 126 \\
\hline \multirow[t]{4}{*}{ E7 Retina } & Control & Control & 9 & 232 \\
\hline & Control & ephrin-A2 & 83 & 142 \\
\hline & Anisomycin & Control & 16 & 210 \\
\hline & Anisomycin & ephrin-A2 & 88 & 184 \\
\hline \multirow[t]{4}{*}{ E7 Retina } & Control & Control & 9 & 267 \\
\hline & Control & ephrin-A2 & 92 & 167 \\
\hline & Puromycin & Control & 7 & 215 \\
\hline & Puromycin & ephrin-A2 & 93 & 162 \\
\hline \multirow[t]{4}{*}{ E7 Retina } & Control & Control & 4 & 154 \\
\hline & Control & slit-3 & 66 & 128 \\
\hline & $\mathrm{CHI}$ & Control & 5 & 209 \\
\hline & $\mathrm{CHI}$ & slit-3 & 66 & 106 \\
\hline \multirow[t]{4}{*}{ E7 Retina } & Control & Control & 9 & 253 \\
\hline & Control & slit-3 & 57 & 165 \\
\hline & Anisomycin & Control & 6 & 219 \\
\hline & Anisomycin & slit-3 & 64 & 148 \\
\hline \multirow[t]{4}{*}{ E7 DRG } & Control & Control & 8 & 183 \\
\hline & Control & Sema3A & 91 & 228 \\
\hline & $\mathrm{CHI}$ & Control & 7 & 210 \\
\hline & $\mathrm{CHI}$ & Sema3A & 93 & 150 \\
\hline \multirow[t]{4}{*}{ E7 DRG } & Control & Control & 6 & 177 \\
\hline & Control & Sema3A & 97 & 107 \\
\hline & Anisomycin & Control & 8 & 106 \\
\hline & Anisomycin & Sema3A & 92 & 78 \\
\hline \multirow[t]{4}{*}{ E13 DRG } & Control & Control & 5 & 184 \\
\hline & Control & Sema3A & 93 & 168 \\
\hline & $\mathrm{CHI}$ & Control & 5 & 214 \\
\hline & $\mathrm{CHI}$ & Sema3A & 95 & 140 \\
\hline \multirow[t]{4}{*}{ E13 DRG } & Control & Control & 9 & 161 \\
\hline & Control & Sema3A & 95 & 199 \\
\hline & Anisomycin & Control & 9 & 143 \\
\hline & Anisomycin & Sema3A & 93 & 149 \\
\hline \multirow[t]{4}{*}{ E7 Symp gang } & Control & Control & 9 & 200 \\
\hline & Control & Sema6A & 86 & 160 \\
\hline & $\mathrm{CHI}$ & Control & 15 & 193 \\
\hline & $\mathrm{CHI}$ & Sema6A & 94 & 188 \\
\hline \multirow[t]{4}{*}{ E7 Symp gang } & Control & Control & 13 & 233 \\
\hline & Control & Sema6A & 82 & 156 \\
\hline & Anisomycin & Control & 10 & 188 \\
\hline & Anisomycin & Sema6A & 95 & 212 \\
\hline \multirow[t]{4}{*}{ E15 mouse DRG } & Control & Control & 7 & 294 \\
\hline & Control & Sema3A & 94 & 188 \\
\hline & $\mathrm{CHI}$ & Control & 12 & 251 \\
\hline & $\mathrm{CHI}$ & Sema3A & 97 & 218 \\
\hline
\end{tabular}

Explants of E7 chick DRG, temporal retina, sympathetic ganglia, or E15 mouse DRG ganglia were cultured on laminin in F-12 with B27. NGF at $10 \mathrm{ng} / \mathrm{ml}$ was added to DRG and sympathetic cultures. After $24 \mathrm{~h}$, explants were treated $15 \mathrm{~min}$ with vehicle or $20 \mu \mathrm{m} C \mathrm{CH}$ or anisomycin, followed by 30 min incubation with guidance cues in continued presence of vehicle or protein synthesis inhibitor. Explants were fixed, and growth cones were scored as collapsed, if they had one filopodium or less. The Mann-Whitney $U$ test was used to assess whether protein synthesis inhibitors significantly altered the collapse data of either vehicle-treated or guidance cue-treated cultures. The test indicated that protein synthesis inhibitors had no effect on intrinsic growth cone collapse and or on responses to repulsive guidance cues.

for the rapid increase in F-actin and growth cone spreading that is induced by NGF.

It is reported that 5 min treatment with netrin or BDNF increased the $\beta$-actin content of Xenopus growth cones (Leung et al., 2006; Yao et al., 2006). We treated DRG explants with NGF for 15 min with or without 15 min CHI pretreatment and then fixed and stained the cultures with $\beta$-actin antibodies (Fig. $7 g-j$ ). By quantitative immunofluorescence, we found that NGF treatment did not increase the total integrated staining for $\beta$-actin in DRG growth cones and distal axons (Fig. $7 k$ ). As noted above, NGF treatment did result in increased F-actin content (Fig. $7 f$ ), and $\beta$-actin distribution was altered in the spread of NGF-treated growth cones, being concentrated at the leading edge. $\mathrm{CHI}$ treatment did not alter total integrated anti- $\beta$-actin staining of growth cones, whether exposed or not exposed to NGF (Fig. $7 i-k$ ). Thus, NGF treatment did not change the $\beta$-actin content of DRG growth cones and distal axons.

\section{Growth cone responses to guidance cues in compartmented dishes}

We used compartmented cultures to ask whether $24 \mathrm{~h}$ inhibition of distal protein synthesis affects growth cone collapse in response to Sema3A. When $1 \mu \mathrm{g} / \mathrm{ml}$ Sema3A was added to axonal compartments treated $24 \mathrm{~h}$ with $\mathrm{CHI}, 73 \%$ of growth cones of E7 DRG neurons collapsed within $10 \min (n=24)$ (Fig. $8 a, b)$.

We found that the spreading response of E7 DRG growth cones to global NGF addition also occurred after inhibiting axonal protein synthesis for $24 \mathrm{~h}$ (Fig. $8 c-f$ ). To investigate whether protein synthesis in axons is required for a long-term turning response to NGF, we used the compartmented culture and placed agarose beads soaked in either NGF or BSA into a collagen matrix that was formed in the axonal compartment (Fig. 8g,h). The collagen matrix included either $20 \mu \mathrm{M} \mathrm{CHI}$ or the control vehicle. After $24 \mathrm{~h}$, we analyzed axon orientation with respect to the NGF or BSA beads. We drew a line halfway between the beads and measured the orientation angle of the terminal $200 \mu \mathrm{m}$ of each axon with respect to the closer bead (Fig. $8 g, h$ ). In gels with control vehicle, the orientation angle to a BSA bead was $14 \pm 7^{\circ}$, whereas orientation to the NGF bead was $46 \pm 4^{\circ}$. These values were statistically different $(p<0.0005)$. In gels containing $20 \mu \mathrm{M} \mathrm{CHI}$, axon orientation toward a BSA bead was $11 \pm 8^{\circ}$, whereas orientation angle toward an NGF bead was $65 \pm 7^{\circ}(p<0.0001)$. Thus, DRG axons elongating from a nerve root into collagen could orient toward an NGFbead despite the continuous presence of CHI. These results show that axonal protein synthesis is not required for DRG growth cones to be guided by an NGF gradient.

\section{Discussion}

Axonal protein synthesis supports multiple functions in adult terminals, including neurotransmission, plasticity, and regeneration (Zheng et al., 2001; Klann and Dever, 2004; Piper and Holt, 2004; Verma et al., 2005; Twiss and van Minnen, 2006; JiménezDíaz et al., 2008). Protein synthesis in developing axons totals $\sim 5 \%$ of neuronal protein (Eng et al., 1999; Lee and Hollenbeck, 


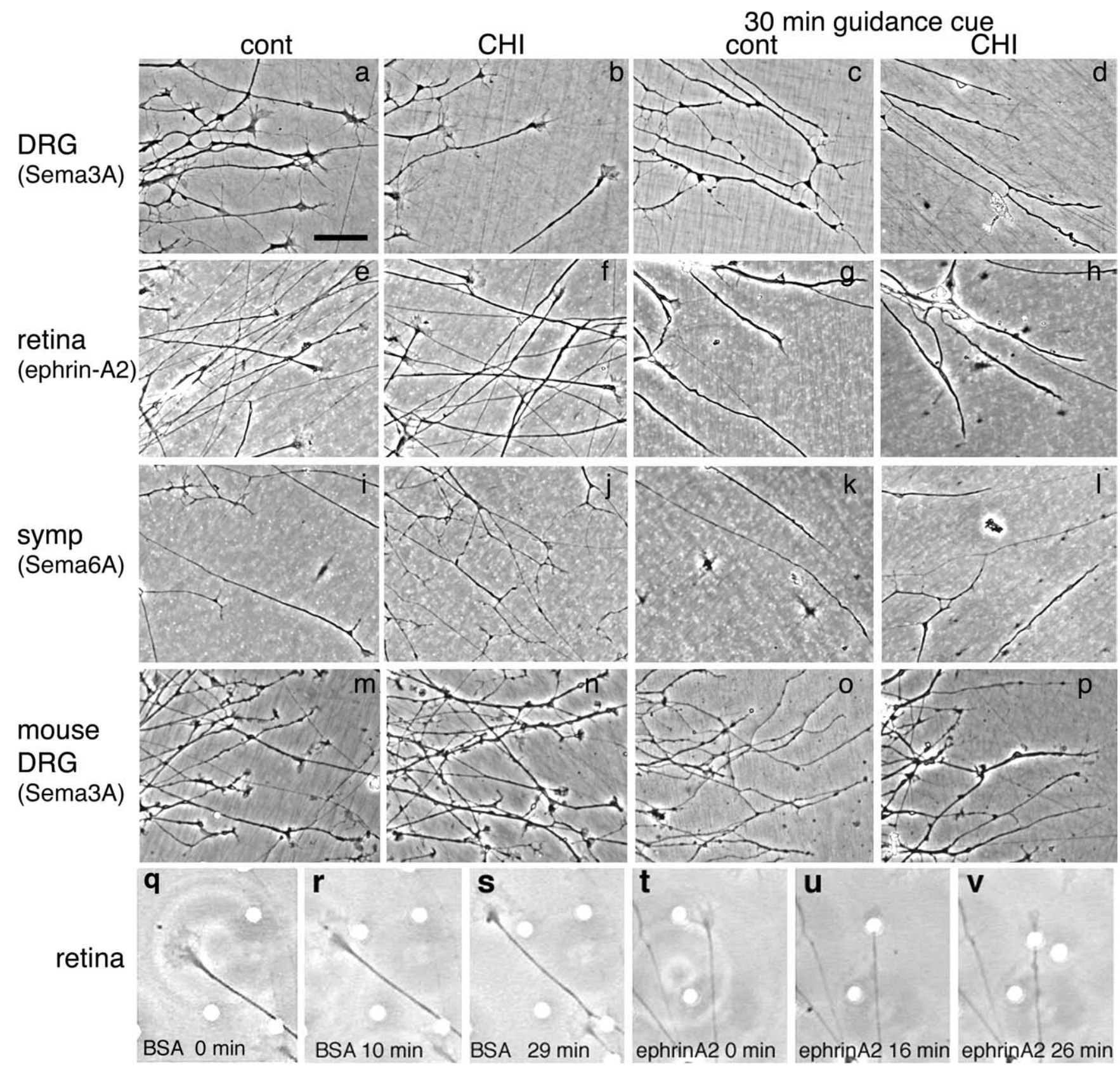

Figure 4. Protein synthesis inhibition does not block responses to repulsive guidance cues. Explants of E7 chick DRGs, temporal retina, sympathetic ganglia, and E15 mouse DRGs were cultured overnight in F-12 with B27. NGF (10 ng/ml) was added to DRG and sympathetic explants. Chick and mouse DRGs were exposed to Sema3A $(\boldsymbol{c}, \boldsymbol{d}, \boldsymbol{o}, \boldsymbol{p})$, temporal retinal explants to ephrin-A2 (f, $\boldsymbol{h})$, and sympathetic explants (symp) to Sema6A $(\boldsymbol{j}, \boldsymbol{I})$ for $30 \mathrm{~min}$. Some explants were pretreated with $\mathrm{CHI}$ for $15 \mathrm{~min}$ before and during exposure to Sema3A (d, $\boldsymbol{p})$, ephrin-A2 (h), or Sema6A (I). Control explants (cont) were exposed to vehicle $(\boldsymbol{a}, \boldsymbol{e}, \boldsymbol{l}, \boldsymbol{m})$ or $\mathrm{CHI}(\boldsymbol{b}, \boldsymbol{f}, \boldsymbol{j}, \boldsymbol{n})$ alone for $45 \mathrm{~min}$. Explants shown as treated with guidance cues are not the same explants as those shown as treated with $\mathrm{CHI}$ or vehicle control. $\boldsymbol{q}$-s show two $\mathrm{CHI}$-treated retinal axons (bottom right and top left) touching and migrating past BSA-coated beads, whereas a $\mathrm{CHI}$-treated retinal axon ( $\boldsymbol{t}$ - $\boldsymbol{v}$ ) stops and collapses after contacting an ephrin-A2-coated bead. Scale bar, $50 \mu \mathrm{m}$.

2003). However, studies with compartmented cultures indicate that axonal growth does not require axonal protein synthesis (Eng et al., 1999; Blackmore and Letourneau, 2007). Recent papers reported that immediate local protein synthesis is required for responses to guidance cues (Lin and Holt, 2007). We investigated this requirement for chick retinal, DRG, and sympathetic neurons and mouse DRG neurons. Unlike other reports, we found that protein synthesis is not required for chick and mouse DRG and chick retinal and sympathetic growth cones to respond to ephrin-A2, slit-3, semaphorins, NGF, and NT-3. Our assays included cues presented globally and cues locally presented on beads or in a gradient. Furthermore, in novel studies in a compartmented dish in which distal axons were in the continuous presence of $\mathrm{CHI}$ but neuronal perikarya were not, axons elongated for hours and growth cones responded to guidance cues in the absence of local protein synthesis. Our results are consistent with two recent publications reporting that protein synthesis is not required for chick retinal growth cone responses to ephrin-A5 (Lang et al., 2008) or for recruitment of DCC (deleted in colorectal cancer) receptors to growth cone surfaces (Bouchard et al., 2008).

Like previous reports, NGF and Sema3A stimulated the phos- 

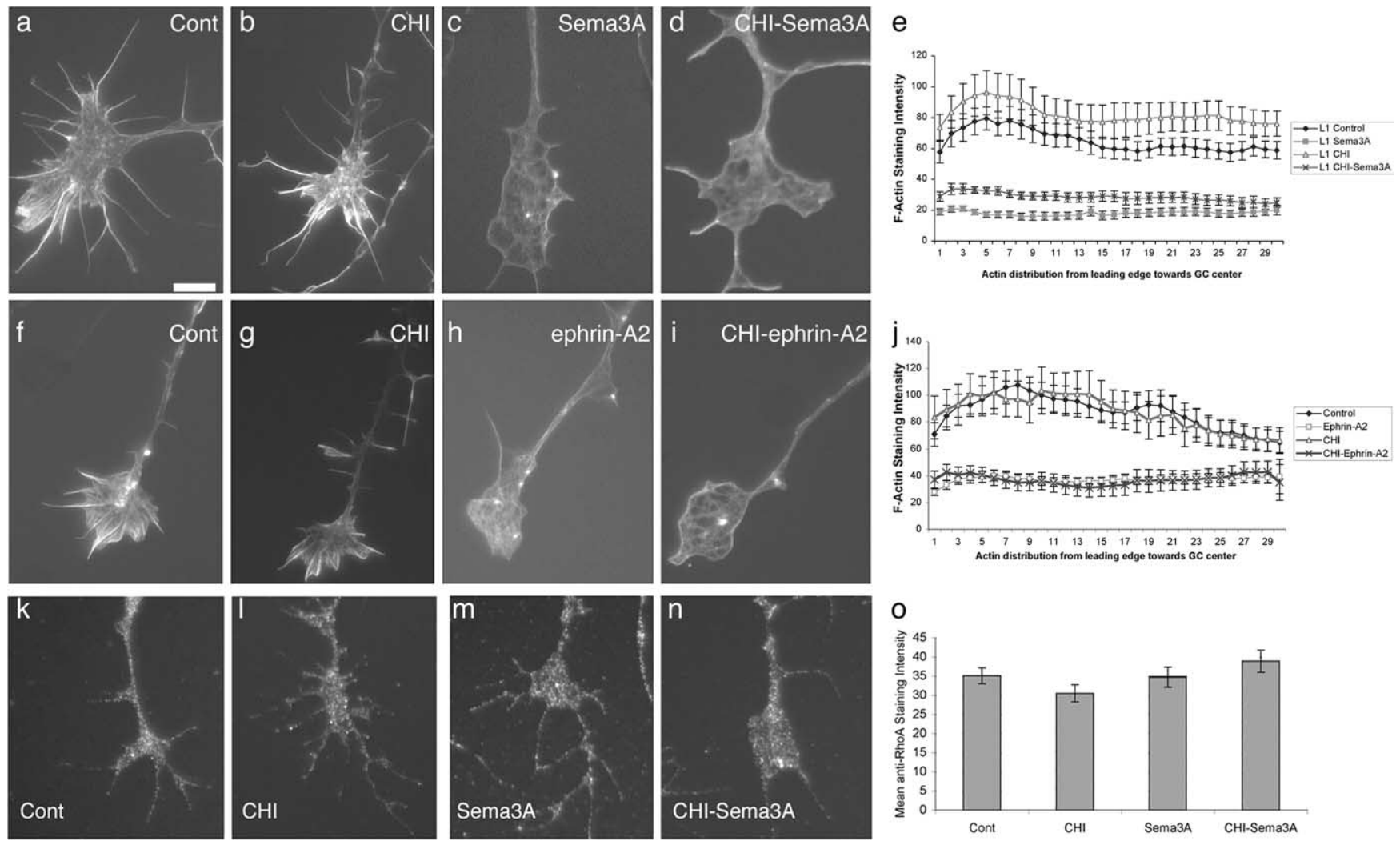

Figure 5. CHI treatment does not affect Sema3A- and ephrin-A2-induced loss of F-actin, and Sema3A does not increase RhoA content of DRG growth cones. E7 DRG explants were cultured overnight in F-12, B27, NGF $(\boldsymbol{a}-\boldsymbol{d}, \boldsymbol{k}-\boldsymbol{n})$, and retinal explants were cultured in F-12, B27 (f-i). Sema3A was added to DRG explants for 15 min with $(\boldsymbol{d}, \boldsymbol{n})$ or without $(\boldsymbol{c}, \boldsymbol{m}) 15$ min $\boldsymbol{C H}$ pretreatment. Ephrin-A2 was added to retinal explants for 15 min with (i) or without $(\boldsymbol{h}) 15 \mathrm{~min}$ CHI pretreatment. Vehicle-treated $(\boldsymbol{a}, \boldsymbol{f}, \boldsymbol{k})$ and $\mathrm{CH}$-treated $(\boldsymbol{b}, \boldsymbol{g}, \boldsymbol{I})$ control explants (Cont) were treated 30 min without repulsive cues. $\boldsymbol{e}, \boldsymbol{j}$, Mean F-actin staining intensities along lines scanned for $6 \mu \mathrm{m}$ backward from the growth cone leading edges. Mean \pm SEM. $\boldsymbol{o}$, Mean pixel intensity of anti-RhoA staining within traced growth cone borders. Scale bar, $10 \mu \mathrm{m}$. Mean \pm SEM, no significant differences.

phorylation of the translation repressor elF-4EBP1. Likewise, nascent protein synthesis in DRG neurons was increased by global addition of NGF or Sema3A. Thus, our findings taken with previous findings (Campbell and Holt, 2001; Takei et al., 2001; Cox et al., 2008) suggest that common mechanisms regulate protein synthesis in developing axons in response to extrinsic factors. However, the relative roles of distally synthesized proteins in axonal functions may depend on metabolic, developmental, or physiologic circumstances of different neurons.

When protein synthesis inhibitors were globally applied to DRG or retinal explants, the axonal growth rate was normal for $1 \mathrm{~h}$, but, eventually, elongation slowed, growth cone motility diminished, and axons retracted. Axonal growth may stop because axonal assembly eventually uses all available components. It may also be that proteins with critical roles in growth cone motility are degraded. We noted that growth cones began to detach and retract during prolonged protein synthesis inhibition. Adhesion receptors that mediate growth cone traction are reutilized via endocytotic/exocytotic recycling (Caswell and Norman, 2006; Dequidt et al., 2007; Tojima et al., 2007). Perhaps, when protein synthesis is blocked, degradative events during recycling exhaust adhesive receptors. In support of this, growth cone detachment and axonal retraction that occurred after prolonged $\mathrm{CHI}$ treatment was delayed, when we also inhibited protein degradation.

When protein synthesis inhibitors were in the axonal compartment of a compartmented chamber, axonal elongation was undiminished for $24 \mathrm{~h}$ or more. This indicates that all proteins necessary for axonal growth are made in perikarya and transported distally. As in previous studies (Eng et al., 1999; Blackmore and Letourneau, 2007), axons in our cultures grew several millimeters without distal protein synthesis. Axons in developing embryos reach their targets after similarly growing several millimeters or less. However, adult projection axons can be 10-100 times longer than when they connected to their targets. Even at these lengths, fast axonal transport can deliver vesicle-bound proteins to terminals in a few hours, but proteins that travel via slow transport, especially cytoskeletal components, take days or weeks to reach ends of long axons. Thus, protein synthesis in adult axons is critical to replace degraded proteins, maintain cytoskeletal integrity, mediate plasticity, and support regeneration (Koenig and Giuditta, 1999; Campenot and Eng, 2000; Zhang and Poo, 2002; Piper and Holt, 2004; Verma et al., 2005; Twiss and van Minnen, 2006; Hengst and Jaffrey, 2007).

Why are our results different from reports that local protein synthesis is required for growth cone responses to guidance cues? One possibility involves the neurons and animal species involved. We used DRG neurons, sympathetic neurons, and retinal neurons from embryonic chicks and mice. Other laboratories used embryonic Xenopus retinal (Campbell and Holt, 2001; Leung et al., 2006; Piper et al., 2006) or spinal cord (Guirland et al., 2003; Yao et al., 2006) neurons, and one study used fetal rat DRGs (Wu et al., 2005). Retinal and DRG neurons are common between these studies, so it is unclear whether these differences are attributable to different neuronal phenotypes. The differentiation state of Xenopus spinal cord neurons is uncertain, because the spinal 

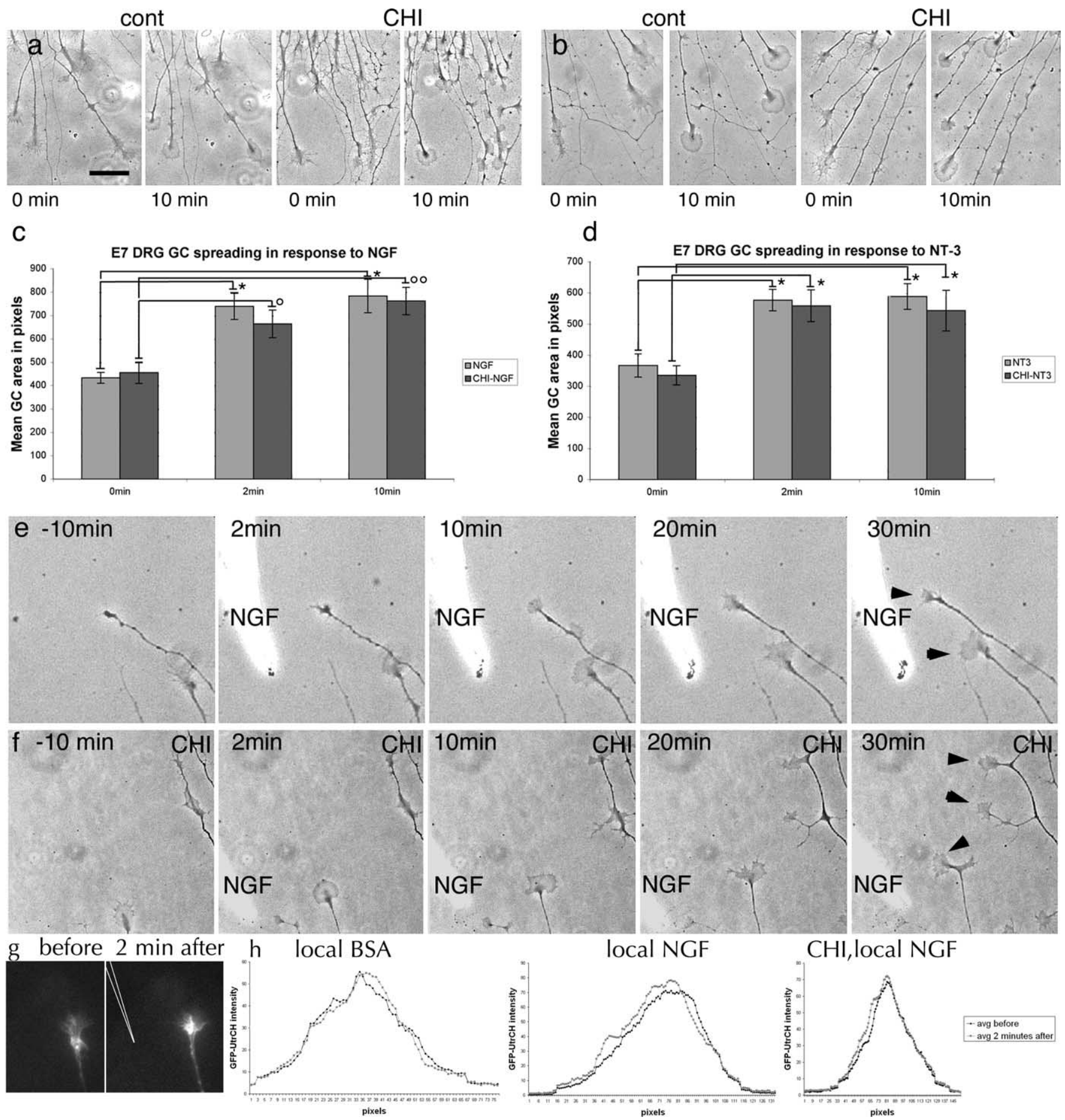

Figure 6. Effects of $\mathrm{CH}$ on growth cone spreading and turning in response to NGF and NT-3. E7 DRG explants were cultured overnight in F-12, B27 on L1. Images were acquired immediately before and $10 \mathrm{~min}$ after adding $40 \mathrm{ng} / \mathrm{ml} \mathrm{NGF}(\boldsymbol{a})$ or NT-3 $(\boldsymbol{b})$. CHI was added for 15 min before and during treatment with NGF $(\boldsymbol{a})$ or NT-3 $(\boldsymbol{b})$. $\boldsymbol{c}, \boldsymbol{d}$, Mean growth cone area in pixels at 0,2 , and 10 min treatment with NGF, ${ }^{*} p<0.0001,{ }^{\circ} p<0.05,{ }^{\circ 0} p<0.001$ (c) or NT-3, ${ }^{*} p<0.002$ (d). Mean \pm SEM. $e$, Time-lapse images of growth cones (arrowheads) turning toward an NGF micropipette. The first image was $10 \mathrm{~min}$ before introducing the pipette, and the following images were 2, 10, 20, and $30 \mathrm{~min}$ later. $f$, Time-lapse images of the attractive turning (arrowheads) of growth cones that were treated with CHI 15 min before and during exposure to an NGF gradient from a micropipette. $\boldsymbol{g}$, GFP-UtrCH distribution in a growth cone before and 2 min after introduction of an NGF micropipette to the left of the growth cone. $\boldsymbol{h}$, The average intensity of GFP-UtrCH fluorescence intensity along line scans drawn across the width of growth cones before and 2 min after introduction of a micropipette that locally releases BSA or NGF. Growth cones in the farthest right panel were exposed to CHI 15 min before introducing the NGF micropipette. Scale bar: $\boldsymbol{a}, \boldsymbol{b}, \boldsymbol{e}-\boldsymbol{g}, 50 \mu \mathrm{m}$.

cords were from young embryos, and the neurons were uncharacterized.

Another source of differences may lie in different levels of metabolism in these in vitro studies. Perhaps, our neurons had high metabolic rates that generated sufficient proteins in the perikarya to supply all growth cone functions. In support of this, after $24 \mathrm{~h}$ culture, E7 DRG axons had extended $>2000 \mu \mathrm{m}$, and E7 retinal axons had extended $>1000 \mu \mathrm{m}$. E7 DRG explants maintained axonal growth rates of $>1 \mathrm{~mm} / \mathrm{d}$ for at least $8 \mathrm{~d}$. These lengths far exceed axon lengths in published figures of Xenopus retinal and spinal neurons or rat DRG neurons. Xenopus spinal cord neuronal axons were 100-200 $\mu \mathrm{m}$ long and were 

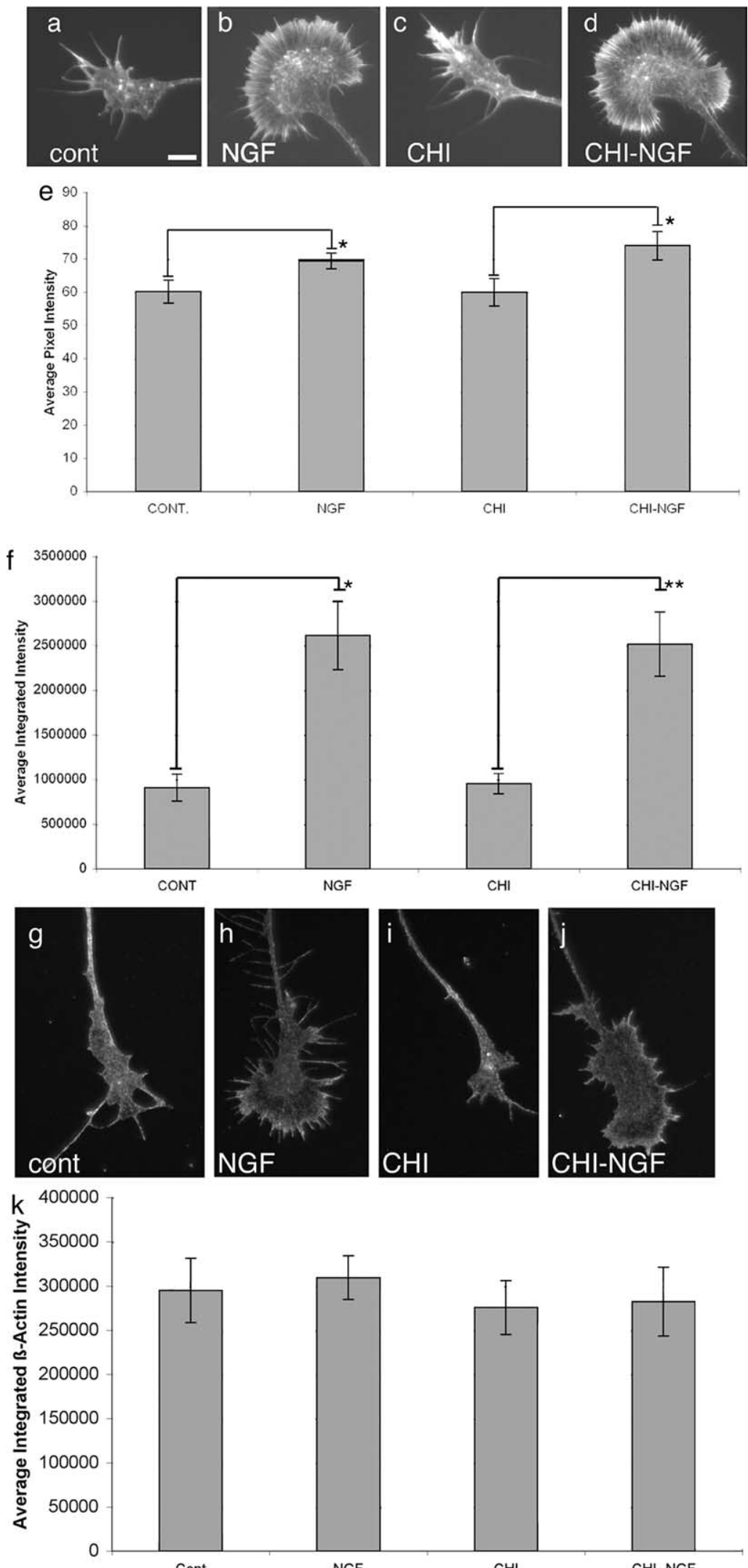

Cont
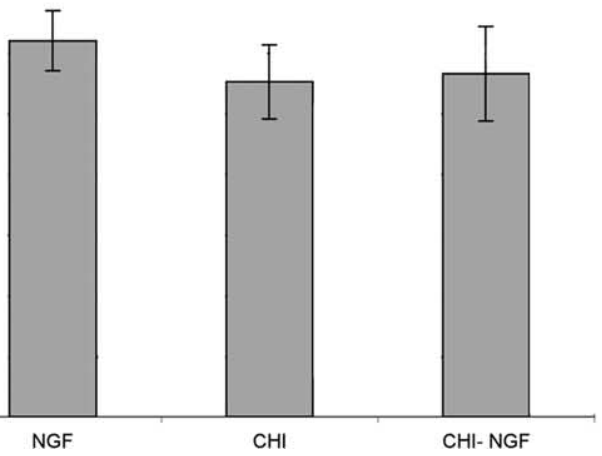

Figure 7. CHI treatment does not affect NGF-induced increase in F-actin, and NGF does not increase $\beta$-actin content of DRG growth cones. E7 DRG explants were cultured overnight in F-12, B27. NGF was added for 15 min with $(\boldsymbol{d}, \boldsymbol{j})$ or without $(\boldsymbol{b}, \boldsymbol{h}) 15 \mathrm{~min}$ pretreatment with CHI. Vehicle-treated $(\boldsymbol{a}, \boldsymbol{g})$ and CHI-treated $(\boldsymbol{c}, \boldsymbol{i})$ control explants (Cont) were treated 30 min without NGF. $\boldsymbol{e}$, Average F-actin staining intensity per pixel. Mean \pm SEM. ${ }^{*} p<0.05$. $f$, Average integrated pixel intensity within traced growth cone borders. Mean \pm SEM. ${ }^{*} p<0.005,{ }^{*} p<0.001$. $\boldsymbol{k}$, Mean integrated anti- $\beta$-actin staining within the distal $30 \mu \mathrm{m}$ of the distal axons and growth cone borders. Mean \pm SEM. Scale bar, $10 \mu \mathrm{m}$. cultured on poly-lysine (Guirland et al., 2003; Yao et al., 2006), unlike the natural substrates we used. Our liquid medium was F-12 with B27 additives, whereas $\mathrm{Xe}$ nopus neurons were cultured in diluted Leibovitz medium with $1 \%$ serum and Ringer's solution. The importance of specific medium components to neuronal metabolism has been appreciated for many years (Bottenstein and Sato, 1979; Chen et al., 2008). Axonal growth by $\mathrm{Xe}$ nopus spinal neurons is most vigorous in the first $12 \mathrm{~h}$, most growth occurs in the first $24 \mathrm{~h}$, and few neurons survive $4 \mathrm{~d}$ (Tabi and Poo, 1991). Another indication of high activity in our neurons was the rapidity of growth cone responses to guidance cues. After adding NGF, growth cone spreading and increased F-actin was evident by $2 \mathrm{~min}$, whereas retinal and DRG growth cones began to collapse within 2 min of adding ephrin-A2 or Sema3A. This rapid response is more consistent with mechanisms that activate signaling pathways rather than protein synthesis. Xenopus retinal growth cone turning toward netrin was not seen until $10 \mathrm{~min}$ after netrin-induced $\beta$-actin synthesis was detected (Leung et al., 2006).

Perhaps, growth cones in our cultures were rich in proteins that function in growth cone motility, whereas levels of these proteins were low in other studies. We found that $45 \mathrm{~min}$ CHI treatment produced no significant decreases in growth cone content of RhoA or $\beta$-actin, as expected if protein levels are high. Neither did 15-30 min treatment of DRG explants with Sema3A or NGF induce detectable increases in RhoA or $\beta$-actin content of growth cones, respectively. Leung et al. (2006) reported that, in Xenopus retinal growth cones, $\beta$-actin staining intensity was 30\% higher after 5 min netrin treatment. Assuming that a retinal growth cone contains 500-1000 ribosomes (Campbell and Holt, 2001) and it takes 1 min to synthesize an actin molecule (Trachsel, 1991), these growth cones would have to initially contain $\sim 17,000$ actin monomers for the addition of 5000 monomers (1000 molecules/min for $5 \mathrm{~min}$ ) to constitute a $30 \%$ increase. Actin and tubulin are the most abundant proteins in chick brain growth cones (Cypher and Letourneau, 1991), and, based on cytoplasmic globular actin pools in chick brain neurons $(30-37 \mu \mathrm{M})$ (Devineni et al., 1999), we estimate that a $10 \times 20 \times 1 \mu \mathrm{m}$ DRG growth cone contains $\sim 4 \times 10^{6} \beta$-actin monomers, $100 \times$ more than Xenopus retinal growth cones. In the studies of Wu et al. (2005), rat DRG explants were cultured for $3 \mathrm{~d}$, and the rat 

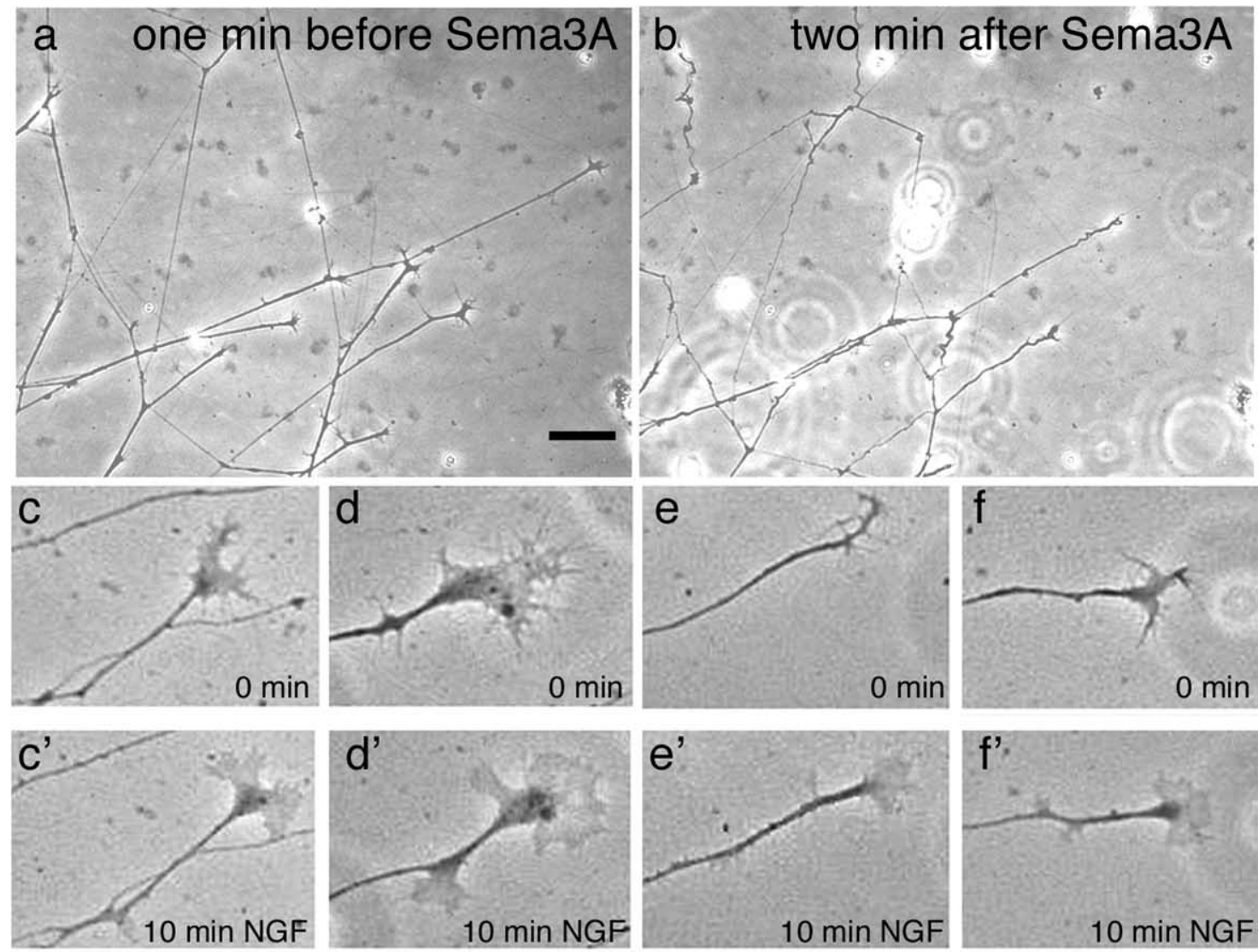

\section{g $18 \mathrm{hr} \mathrm{CHI}$}
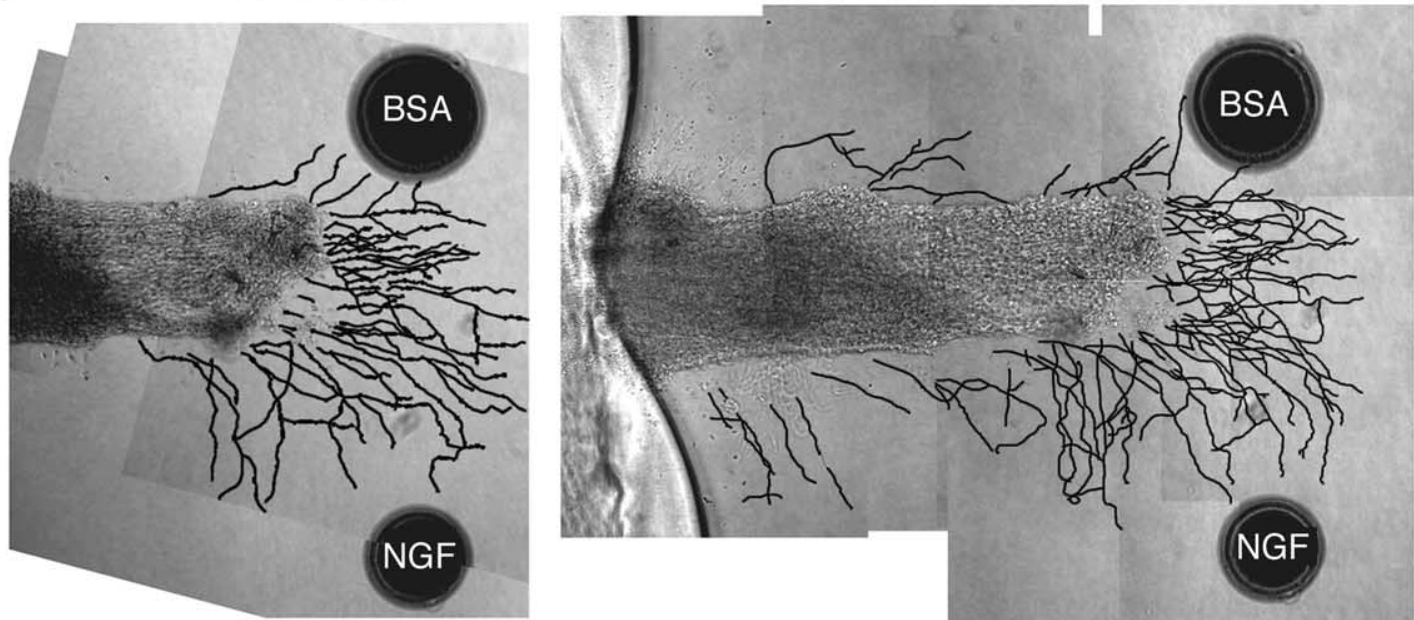

Figure 8. Growth cone responses to Sema3A and NGF are not inhibited by $24 \mathrm{~h} \mathrm{CHI} \mathrm{treatment} \mathrm{in} \mathrm{axon} \mathrm{compartment.} \mathrm{E7} \mathrm{DRG} \mathrm{explants} \mathrm{were} \mathrm{cultured} \mathrm{overnight} \mathrm{in} \mathrm{F-12,} \mathrm{B27} \mathrm{in} \mathrm{compartmented}$ chambers with $20 \mu \mathrm{M} C H$ in the axon compartment. $\boldsymbol{a}, \boldsymbol{b}$, Growth cones $1 \mathrm{~min}$ before $(\boldsymbol{a})$ and $2 \mathrm{~min}$ after $(\boldsymbol{b})$ adding $1 \mu \mathrm{g} / \mathrm{ml} \mathrm{Sema} 3 \mathrm{~A}$. Growth cones collapsed. $\boldsymbol{c}-\boldsymbol{f}^{\prime}$, Growth cones $0 \mathrm{~min}$ before $(\boldsymbol{c}-\boldsymbol{f})$ and $10 \mathrm{~min}$ after $\left(\boldsymbol{c}^{\prime}-\boldsymbol{f}^{\prime}\right)$ adding $40 \mathrm{ng} / \mathrm{ml}$ NGF. Increased growth cone spreading is seen. $\boldsymbol{g}$ and $\boldsymbol{h}$ show montages of axon growth from the end of a CHI-treated peripheral root in a collagen matrix containing an NGF- and a BSA-soaked bead. Axons are traced in black. Axon orientation toward the NGF bead, but not the BSA bead, is seen. Scale bar: $\boldsymbol{a}, \boldsymbol{b}, 50 \mu \mathrm{m} ; \boldsymbol{c}-\boldsymbol{f}, 20 \mu \mathrm{m} ; \boldsymbol{g}, \boldsymbol{h}, 150 \mu \mathrm{m}$.

DRG axons had reached $400-500 \mu \mathrm{m}$ long, which is one-quarter the length of our E7 chick DRG axons after $20 \mathrm{~h}$. As seen in the study of Wu et al. (2005), their Figure 3a, RhoA was barely detectable in embryonic rat DRG growth cones. Conversely, our DRG growth cones stained robustly for RhoA with or without Sema3A treatment, and we found that migrating growth cones in $8 \mathrm{~d}$ in vitro DRG cultures collapsed rapidly in response to Sema3A, even with CHI treatment. Our results are consistent with the hypothesis that growth cones of actively growing axons contain sufficient RhoA and $\beta$-actin to respond to guidance cues without protein synthesis. Although our data show that guidance cues stimulate protein synthesis in axons of E7 DRG neurons, our data also show that these events do not detectably increase growth cone levels of RhoA or $\beta$-actin and are not required for responding to guidance cues.

Global treatment with CHI did affect DRG growth cones. Although globally inhibiting protein synthesis for up to $45 \mathrm{~min}$ did not significantly affect growth cone responses, discrete changes 
from lacking key proteins may occur. After $2 \mathrm{~h}$ CHI treatment, DRG growth cones did not spread in response to NGF. Globally applied CHI reduced the turning of DRG growth cones toward NGF. Turning is more complex than growth cone spreading and may involve exocytosis of vesicle-associated proteins (Tojima et al., 2007) that are transported at fast transport rates of 50-400 $\mathrm{mm} / \mathrm{d}$ (Squire et al., 2008). Such proteins could be moved from the perikaryon to the tip of a $1000 \mu \mathrm{m}$ axon in $4-30 \mathrm{~min}$ (or $30 \mathrm{~s}$ to $3 \mathrm{~min}$ in a $100 \mu \mathrm{m}$ Xenopus spinal neuron axon), which is within the duration of a turning response. Thus, because vesicle transport is rapid, globally applied protein synthesis inhibitors cannot distinguish a growth cone location from a cell body location for protein synthesis that is necessary for growth cone turning. In an attempt to eliminate contributions of perikaryonderived proteins to growth cone responses, some studies isolated growth cones from cell bodies by severing axons (Campbell and Holt, 2001; Ming et al., 2002; Wu et al., 2005). However, the isolated axons were damaged, because most did not recover growth cones (Ming et al., 2002). In another study of severed axons (Zheng et al., 2001), cycloheximide treatment induced retraction of isolated axons, but axons of intact neurons did not retract after cycloheximide treatment.

Therefore, unlike previous reports, we used compartmented dishes to examine whether distal axonal protein synthesis is required for responses to guidance cues. Because DRG growth cones responded to globally applied Sema3A or NGF and could turn toward an NGF source when distal protein synthesis was inhibited for $24 \mathrm{~h}$, our results clearly showed that proteins made in the perikaryon and transported to growth cones are sufficient for axonal elongation and growth cone guidance.

In summary, we confirmed that guidance cues stimulate protein synthesis in distal axons. Protein synthesis may occur in axons from the earliest neuronal polarization and axonal differentiation, via targeted mRNA transport into axons and signaling by extrinsic cues to regulate mRNA translation (Kiebler and Bassell, 2006). Extrinsic cues such as Sema3A and NGF may regulate axonal mRNA translation throughout this period, during navigation to targets, later as axons branch, and are remodeled into terminal fields, and in mature organisms to maintain terminals and to respond to stimuli or injury. Our in vitro results indicate that proteins made in distal axons of chick neurons are not necessary for axonal elongation and growth cone responses to guidance cues, whereas other in vitro studies indicate that distally synthesized proteins are required for responses to guidance cues. As noted above, higher metabolic activity in our neurons may explain these differences in in vitro studies. Perhaps, in embryos the relative contributions of locally translated proteins such as RhoA and $\beta$-actin to total growth cone pools is initially low as immature axons rapidly elongate to their targets. Later, the significance of distal axon protein synthesis may increase, as axons reach their targets, elongate by intercalary growth to become the greatest part of neuronal mass (Pfister et al., 2004), and form mature endings in a complex environment. Local protein synthesis may become highly important as axon terminals become locally distinct in form and function. In vivo studies across the time span of development are needed to more clearly understand the roles of distal protein synthesis in axonal morphogenesis.

\section{References}

Blackmore M, Letourneau PC (2007) Protein synthesis in distal axons is not required for axon growth in the embryonic spinal cord. Dev Neurobiol 67:976-986.

Bottenstein JE, Sato GH (1979) Growth of a rat neuroblastoma cell line in serum-free supplemented medium. Proc Natl Acad Sci U S A 76:514-517.

Bouchard JF, Horn KE, Stroh T, Kennedy TE (2008) Depolarization recruits DCC to the plasma membrane of embryonic cortical neurons and enhances axon extension in response to netrin-1. J Neurochem 107:398-417.

Bramham CR, Wells DG (2007) Dendritic mRNA: transport, translation and function. Nat Rev Neurosci 8:776-789.

Brittis PA, Lu Q, Flanagan JG (2002) Axonal protein synthesis provides a mechanism for localized regulation at an intermediate target. Cell 110:223-235.

Brunet I, Weinl C, Piper M, Trembleau A, Volovitch M, Harris W, Prochiantz A, Holt C (2005) The transcription factor Engrailed-2 guides retinal axons. Nature 438:94-98.

Burkel BM, von Dassow G, Bement WM (2007) Versatile fluorescent probes for actin filaments based on the actin-binding domain of utrophin. Cell Motil Cytoskeleton 64:822-832.

Campbell DS, Holt CE (2001) Chemotropic responses of retinal growth cones mediated by rapid local protein synthesis and degradation. Neuron 32:1013-1026.

Campenot RB, Eng H (2000) Protein synthesis in axons and its possible functions. J Neurocytol 29:793-798.

Caswell PT, Norman JC (2006) Integrin trafficking and the control of cell migration. Traffic 7:14-21.

Chen Y, Stevens B, Chang J, Milbrandt J, Barres BA, Hell JW (2008) NS21: re-defined and modified supplement B27 for neuronal cultures. J Neurosci Methods 171:239-247.

Cox LJ, Hengst U, Gurskaya NG, Lukyanov KA, Jaffrey SR (2008) Intraaxonal translation and retrograde trafficking of CREB promotes neuronal survival. Nat Cell Biol 10:149-159.

Cypher C, Letourneau PC (1991) Identification of cytoskeletal, focal adhesion, and cell adhesion proteins in growth cone particles isolated from developing chick brain. J Neurosci Res 30:259-265.

Dahm R, Macchi P (2007) Human pathologies associated with defective RNA transport and localization in the nervous system. Biol Cell 99:649-661.

Dequidt C, Danglot L, Alberts P, Galli T, Choquet D, Thoumine O (2007) Fast turnover of $\mathrm{L} 1$ adhesion in neuronal growth cones involving both surface diffusion and exo/endocytosis of L1 molecules. Mol Biol Cell 18:3131-3143.

Devineni N, Minamide LS, Niu M, Safer D, Verma R, Bamburg JR, Nachmias VT (1999) A quantitative analysis of G-actin binding proteins and the G-actin pool in developing chick brain. Brain Res 823:129-140.

Eng H, Lund K, Campenot RB (1999) Synthesis of B-tubulin, actin, and other proteins in axons of sympathetic neurons in compartmented cultures. J Neurosci 19:1-9.

Fan J, Mansfield SG, Redmond T, Gordon-Weeks PR, Raper JA (1993) The organization of F-actin and microtubules in growth cones exposed to a brain-derived collapsing factor. J Cell Biol 121:867-878.

Farrar NR, Spencer GE (2008) Pursuing a "turning point" in growth cone research. Dev Biol 318:102-111.

Gallo G, Letourneau PC (2000) Neurotrophins and the dynamic regulation of the neuronal cytoskeleton. J Neurobiol 44:159-173.

Guan KL, Rao Y (2003) Signaling mechanisms mediating neuronal responses to guidance cues. Nat Rev Neurosci 4:941-956.

Guirland C, Buck KB, Gibney JA, DiCicco-Bloom E, Zheng JQ (2003) Direct cAMP signaling through G-protein-coupled receptors mediates growth cone attraction induced by pituitary adenlyate cyclase-activating peptide. J Neurosci 23:2274-2283.

Hengst U, Jaffrey SR (2007) Function and translational regulation of mRNA in developing axons. Semin Cell Dev Biol 18:209-215.

Hu H, Marton TF, Goodman CS (2001) Plexin B mediates axon guidance in Drosophila by simultaneously inhibiting active Rac and enhancing RhoA signaling. Neuron 32:39-51.

Jiménez-Díaz L, Géranton SM, Passmore GM, Leith JL, Fisher AS, Berliocchi L, Sivasubramaniam AK, Sheasby A, Lumb BM, Hunt SP (2008) Local translation in primary afferent fibers regulates nociception. PloS ONE 3:e1961.

Kiebler MA, Bassell GJ (2006) Neuronal RNA granules: movers and makers. Neuron 51:685-690.

Klann E, Dever TE (2004) Biochemical mechanisms for translational regulation in synaptic plasticity. Nat Rev Neurosci 5:931-942. 
Koenig E, Giuditta A (1999) Protein-synthesizing machinery in the axon compartment. Neuroscience 89:5-15.

Lang S, von Philipsborn AC, Bernard A, Bonhoeffer F, Bastmeyer M (2008) Growth cone response to ephrin gradients produced by microfluidic networks. Anal Bioanal Chem 390:809-816.

Lee DH, Goldberg AL (1996) Selective inhibitors of the proteosomedependent and vacuolar pathways of protein degradation in Saccharomyces cerevisae. J Biol Chem 271:27280-27284.

Lee SK, Hollenbeck PJ (2003) Organization and translation of mRNA in sympathetic axons. J Cell Sci 116:4467-4478.

Leung KM, van Horck FP, Lin AC, Allison R, Standart N, Holt CE (2006) Asymmetrical $\beta$-actin mRNA translation in growth cones mediates attractive turning to netrin-1. Nat Neurosci 9:1247-1256.

Li C, Sasaki Y, Takei K, Yamamoto H, Shouji M, Sugiyama Y, Kawakami T, Nakamura F, Yagi T, Ohshima T, Goshima Y (2004) Correlation between semaphorin3A-induced facilitation of axonal transport and local activation of a translation initiation factor eukaryotic translation initiation factor 4E. J Neurosci 24:6161-6170.

Lin AC, Holt CE (2007) Local translation and directional steering in axons. EMBO J 26:3729-3736.

Ludueña MA (1973) Nerve cell differentiation in vitro. Dev Biol 33:268-284.

Ming G, Lohof AM, Zheng JQ (1997) Acute morphogenic and chemotropic effects of neurotrophins on cultured Xenopus spinal neurons. J Neurosci 17:7860-7871.

Ming GL, Wong ST, Henley J, Yuan XB, Song HJ, Spitzer NC, Poo MM (2002) Adaptation in the chemotactic guidance of nerve growth cones. Nature 417:411-418.

Oppenheim RW, Prevette D, Tytell M, Homma S (1990) Naturally occurring and induced neuronal death in the chick embryo in vivo requires protein and RNA synthesis: evidence for the role of cell death genes. Dev Biol 138:104-113.

Pfister BJ, Iwata A, Meaney DF, Smith DH (2004) Extreme stretch growth of integrated axons. J Neurosci 24:7978-7983.

Piper M, Holt C (2004) RNA translation in axons. Annu Rev Cell Dev Biol 20:505-523.

Piper M, Anderson R, Dwivedy A, Weinl C, van Horck F, Leung KM, Cogill E, Holt C (2006) Signaling mechanisms underlying Slit2-induced collapse of Xenopus retinal growth cones. Neuron 49:215-228.

Prins KW, Lowe DA, Ervasti JM (2008) Skeletal muscle-specific ablation of $\gamma$-actin does not exacerbate the mdx phenotype. PloS ONE 3:e2419.

Squire LR, Berg D, Bloom FE, du Lac S, Ghosh A, Spitzer NC, eds (2008) Fundamental neuroscience, Ed 3. Burlington, MA: Elsevier.

Steward O, Schuman EM (2003) Compartmentalized synthesis and degradation of proteins in neurons. Neuron 40:347-359.

Tabi N, Poo MM (1991) Culturing spinal neurons and muscle cells from
Xenopus embryos. In: Culturing nerve cells (Banker G, Goslin K, eds), pp. 137-154. Cambridge, MA: MIT.

Takei N, Kawamura M, Hara K, Yonezawa K, Nawa H (2001) Brain-derived neurotrophic factor enhances neuronal translation by activating multiple initiation processes. J Biol Chem 276:42818-42825.

Tojima T, Akiyama H, Itofusa R, Li Y, Katayama H, Miyawaki A, Kamiguchi $\mathrm{H}$ (2007) Attractive axon guidance involves asymmetric membrane transport and exocytosis in the growth cone. Nat Neurosci 10:58-66.

Trachsel H (1991) Translation in eukaryotes. Boca Raton, FL: CRC.

Tursun B, Schlüter A, Peters MA, Viehweger B, Ostendorff HP, Soosairajah J, Drung A, Bossenz M, Johnsen SA, Schweizer M, Bernard O, Bach I (2005) The ubiquitin ligase Rnf6 regulates LIM kinase I levels in axonal growth cones. Genes Dev 19:2307-2319.

Twiss JL, van Minnen J (2006) New insights into neuronal regeneration: the role of axonal protein synthesis in pathfinding and axonal extension. J Neurotrauma 23:295-308.

Verma P, Chierzi S, Codd AM, Campbell DS, Meyer RL, Holt CE, Fawcett JW (2005) Axonal protein synthesis and degradation are necessary for efficient growth cone regeneration. J Neurosci 25:331-342.

Wahl S, Barth H, Ciossek T, Aktories K, Mueller BK (2000) Ephrin-A5 induces collapse of growth cones by activating Rho and Rho kinase. J Cell Biol 149:263-270.

Wang W, van Niekerk E, Willis DE, Twiss JL (2007) RNA transport and localized protein synthesis in neurological disorders and neural repair. Dev Neurobiol 67:1166-1182.

Weinl C, Becker N, Loeschinger J (2005) Responses of temporal retinal growth cones to ephrinA5-coated beads. J Neurobiol 62:219-230.

Wu KY, Hengst U, Cox LJ, Macosko EZ, Jeromin A, Urquhart ER, Jaffrey SR (2005) Local translation of RhoA regulates growth cone collapse. Nature 436:1020-1024.

Yao J, Sasaki Y, Wen Z, Bassell GJ, Zheng JQ (2006) An essential role for beta-actin mRNA localization and translation in $\mathrm{Ca}^{2+}$-dependent growth cone guidance. Nat Neurosci 9:1265-1273.

Zhang HL, Singer RH, Bassell GJ (1999) Neurotrophin regulation of betaactin mRNA and protein localization within growth cones. J Cell Biol 147:59-70.

Zhang HL, Eom T, Oleynikov Y, Shenoy SM, Liebelt DA, Dictenberg JB, Singer RH, Bassell GJ (2001) Neurotrophin-induced transport of a betaactin mRNP complex increases beta-actin levels and stimulates growth cone motility. Neuron 31:261-275.

Zhang X, Poo MM (2002) Localized synaptic potentiation by BDNF requires local protein synthesis in the developing axon. Neuron 36:675-688.

Zheng JQ, Kelly TK, Chang B, Ryazantsev S, Rajasekaran AK, Martin KC, Twiss JL (2001) A functional role for intra-axonal protein synthesis during axonal regeneration from adult sensory neurons. J Neurosci 21:92919303. 